\title{
Vulnerabilidad sísmica y capacidad de carga de un puente atirantado basados en confiabilidad estructural
}

\section{Seismic vulnerability and loading capacity of a wire strained bridge based on structural reliability}

\author{
Edgar M uñoz*1, Federico Núñez*, Jorge A. Rodríguez*, Alfonso Ramos*, Camilo o tálora* \\ * Pontificia Universidad Javeriana. CO LO M BIA \\ Fecha de recepción: 10/09/2009 \\ (06/ 07/2010 \\ PAG. $285-323$
}

\begin{abstract}
Resumen
Se presenta en este documento los análisis de vulnerabilidad sísmica y de capacidad de carga del Viaducto Cesar Gaviria Trujillo, empleando las técnicas de confiabilidad estructural basada en las labores de instrumentación. En él se incluye labores tales como: ensayos geofísicos, ensayos de las propiedades mecánicas de materiales, vibraciones ambiéntales, medición de los efectos de la cargas vehiculares, instrumentación inalámbrica, pruebas de carga, medición de tensiones de tirantes, etc. También se explican los modelos estructurales en elementos finitos desarrollados para el puente y su proceso de calibración basado en la prueba de carga y las propiedades dinámicas determinadas experimentalmente. Además la forma como se realizó la reconstrucción de las historias de esfuerzos de todos los elementos estructurales durante su construcción, de acuerdo con la bitácora de obra. Para los análisis de confiabilidad se hizo un estudio de amenaza sísmica y respuesta dinámica del sitio del puente, donde se obtuvieron nueve espectros de respuesta con diferentes periodos de retorno. Al estudiar las curvas de probabilidad de resistencia y solicitaciones sísmicas de los pilones, se encontró que tienen unos índices de confiabilidad adecuados dentro de las recomendaciones de las normas internacionales. Además que uno de los elementos de la superestructura que se instrumentó para evaluar su capacidad para los efectos de tráfico, tiene un índice de confiabilidad por fuera de los rangos sugeridos por las normas internacionales. Finalmente algunos tirantes tienen niveles de tensiones mayores a las admisibles especificadas durante su diseño y a las recomendadas internacionalmente para este tipo de puentes.
\end{abstract}

Palabras Clave: Confiabilidad estructural, vulnerabilidad sísmica, puentes atirantados, efectos locales, monitoreo, capacidad de carga, historia de esfuerzos y proceso constructivo

Abstract

This document presents the analysis of seismic vulnerability and load capacity for Cesar Gaviria Trujilo Viaduct, by means of structural reliability techniques based on instrumentation works. Such study includes: geophysical trial tests, trials tests on material mechanical properties, environmental vibrations, measurements on the effects of traffic load, wireless instrumentation, loading tests, wire strainers tensile strength, etc. Additionally, the study explains structural models on finite elements, which were developed for the bridge, as well as its calibration process based on the loading test, and dynamical properties determined on experimental basis. Furthermore, the study indicates the way stress records collection of all structural elements was conducted, during the construction process, in accordance with the job site log-book. As for reliability, a seismic threat analysis was made as well as dynamic responses on the bridge site, where nine spectrums were obtained at different return periods. By studying strength probability curves and seismic loads of pylons, it was found they have reliability indexes in accordance with recommendations by the international regulations. However, one of the superstructure's elements, which were introduced to evaluate its capacity on traffic effects, has a reliability index far higher than the ranges recommended by international regulations. Finally, some wire strainers have higher level tensions than specifications admitted during its design and international recommendations for these kinds of bridges.

Keywords: Structural reliability, seismic vulnerability, wire strained bridges, local effects, monitoring, loading capacity, stress record and constructive process

\section{Introduction}

This study was conducted under the joint cooperation by the Instituto Nacional de Vias (IN VIAS) and the Pontificia Universidad Javieriana (PUJ), which yielded some results used as inputs by the engineering company ICAGEL, who had the responsibility of diagnosing, maintenance and rehabilitation.

\footnotetext{
${ }^{1}$ Autor de correspondencia / Corresponding author: E-mail: edgar.munoz@javeriana.edu.co
} 
Such study was done under a Company-State-U niversity alliance, where we provided the know-how of a Structure research team in this field, well experienced in reliability studies for other bridges having different typologies, scopes and sensitive characteristics, such as Puerto Salgar Bridge, Cajamarca Bridge and Rio N egro Bridge (See [Muñoz E. et al., 2002], [M uñoz E. et al., 2005], [Muñoz E. et al., 2006] and [Muñoz E. et al., 2008]).

The viaduct called Cesar Gaviria Tujillo, is a wire strained structure that connects Pereira and Dosquebradas cities, which are located in Colombia west side, alongside 0 tun River. Deck Bridge's total width is $26.80 \mathrm{mt}$ (including leaf bridges) and has (4) four lanes each one $3.50 \mathrm{mt}$. long. Its total length is $440 \mathrm{mt}$, having two (2) end spans of $31.2 \mathrm{mt}$ long, two side spans 83.25 $\mathrm{mt}$. long, and one central span $210.9 \mathrm{mt}$. long. Such deck bridge is a wire strained structure made of reinforced steel beams, longitudinal and transverse (spaced at 3.7 meters), and of a reinforced concrete slab of $25 \mathrm{~cm}$ thickness with shear strain connectors. The bridge is made of two (2) reinforced concrete pylons, which are strongly founded by bearing piles up to 30 meters depth. Pereira's pylon is 96.77 meters high, and Dosquebradas pylon is 107.97 meters high. They both have variable box girder sections and a post-stressed transversal beam. This bridge deck is supported by a total of 72 wire strainers of Freyssinet technology (Freyssinet, 2000), arranged in a half-tan shape rising up from two aforementioned pylons, erected $55 \mathrm{mt}$ above bridge deck (See Figure 1 and Figure 2).

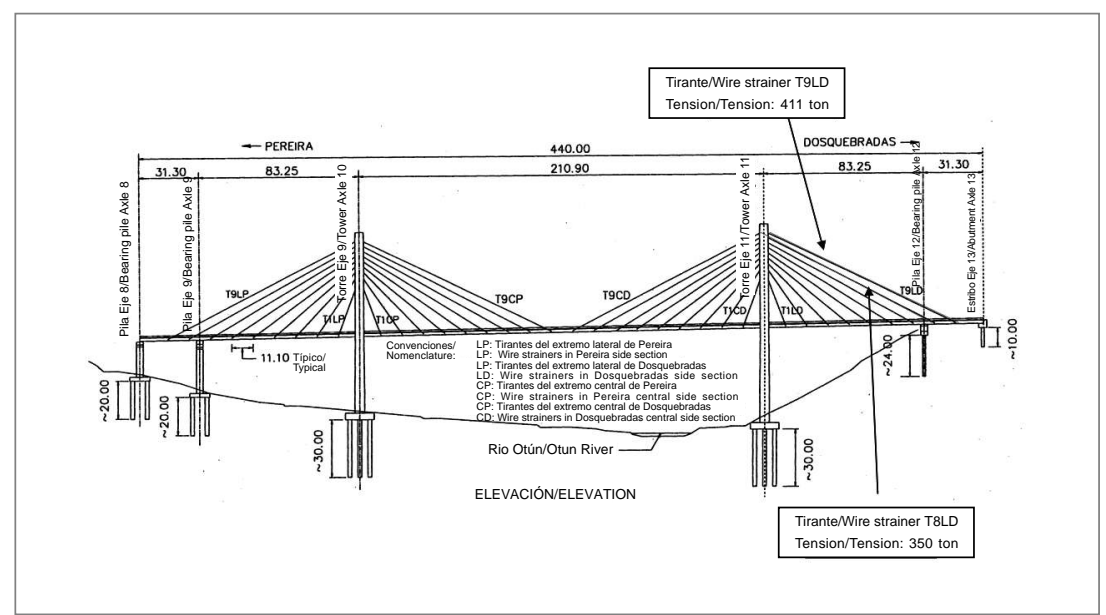

Figura 1. Esquema longitudinal del Viaducto. Localización de dos (2) de los tres (3) tirantes seleccionados para medir sus tensiones (Marín, J.M, 1999)

Figure 1. Viaduct longitudinal scheme. Locations of two (2) of three (3) wire strainers selected to measure tensile strength (Marin, J.M., 1999) 


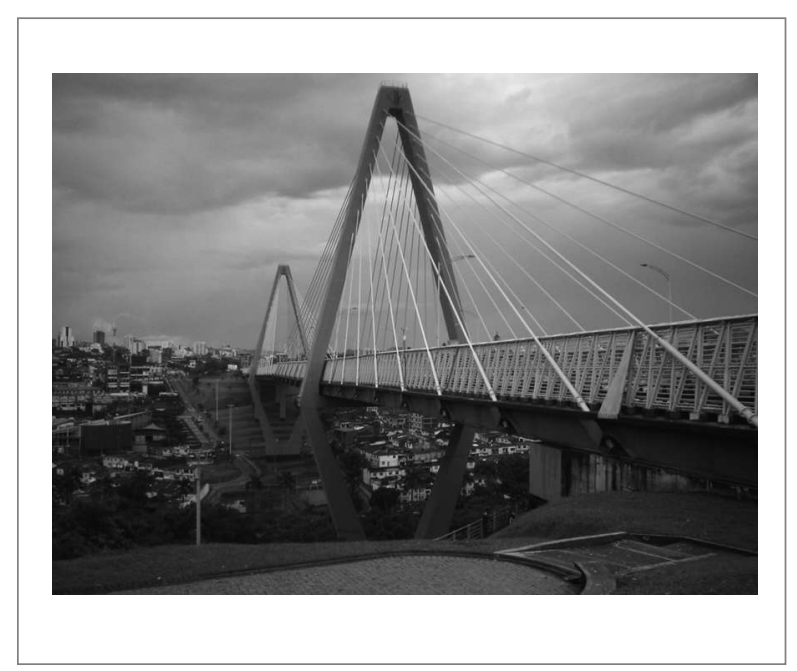

Figura 2. Perfil del puente atirantado Figure 2. Wire strained bridge - side view

\section{Development of the work}

This work was developed according to the following stages:

\subsection{Bride material trials}

This bridge was designed and constructed under the following material specifications (See Marín, J. M, 1999):

Tabla 1. Especificaciones de diseño de los materiales del puente Table 1. Design specifications for bridge materials

\begin{tabular}{|c|c|}
\hline Material & Característica/Parameter \\
\hline Concreto/Concrete & $\begin{array}{l}\text { - Resistencia nominal a la compresión/D esign compresión strenght: fc=35 M pa } \\
\text { - Módulo de elasticidad/Elasticity Modulus: Ec }=28.5 \mathrm{Gpa} \\
\text { - Peso específico del hormigón reforzado de las losas de concreto es de } 26 \mathrm{KN} / \mathrm{m} 3 \text { (comprobado } \\
\text { con ensayo de laboratorio)/U nit weight of slab reinforced concrete }=26 \mathrm{kN} / \mathrm{m} 3 \text { (laboratory tested) }\end{array}$ \\
\hline Acero de Refuerzo/Rebar & $\begin{array}{l}\text { - Resistencia a la fluencia/Yield strength: Fy=420 M Pa } \\
\text { - Módulo de elasticidad/Elasticity M odulus: Es=200 GPa }\end{array}$ \\
\hline $\begin{array}{l}\text { Acero estructural/Structural Steel } \\
\text { Tipo/Type (M/223 GR 50) }\end{array}$ & $\begin{array}{l}\text { - Esfuerzo mínimo de fluencia/M inimun yield stress: } 350 \text { M Pa } \\
\text { - Módulo de elasticidad/Elasticity Modulus: } 210 \mathrm{GPa}\end{array}$ \\
\hline $\begin{array}{l}\text { Acero de preesfuerzo de baja relajación/ } \\
\text { Low relaxation pre-stress steel }\end{array}$ & $\begin{array}{l}\text { - Esfuerzo de rotura/Fracture strength: fpu=1230 M Pa } \\
\text { - Módulo de elasticidad/Elasticity M odulus: } E p=205 \text { GPa }\end{array}$ \\
\hline $\begin{array}{l}\text { Acero de tirantes de baja relajación/ } \\
\text { Low Relaxation Steel for Cables }\end{array}$ & $\begin{array}{l}\text { - Esfuerzo de rotura/Fracture strenght: fpu=1862 } \\
\text { - Módulo de elasticidad/Elasticity M odulus: } E p=195 \mathrm{GPa}\end{array}$ \\
\hline
\end{tabular}


During the construction, bridge materials were subject to detailed quality control analysis and furthermore, two (2) wire strainers were fatigue tested by LPC (Nates, France), obtaining satisfactory results. So as to conduct reliability analysis and to be able to perform strength reliability curves, cores were drawn and used to evaluate steel strength. Such process was conducted at the U niversidad de Los Andes material laboratory, confirming that steel is of A-50 type having average fluency strength of 383 M Pa (see Table 2). Such stress values for nominal concrete strength, were used for determining strength structural curves on monitored elements. Additionally, concrete strength was researched on some bridge's elements. For that purpose the company ICAGEL developed trial tests for: pylons (average fc, 34.3 MPa), deck slab (average fc, 36.8 MPa) and abutment (average fc, 28.3 MPa).

Tabla 2. Resultados de los ensayos mecánicos realizados al acero Table 2. Results of mechanical trial tests made on steel

\begin{tabular}{|c|c|c|c|c|c|c|}
\hline $\begin{array}{l}\text { Muestra/ } \\
\text { Sample }\end{array}$ & $\begin{array}{l}\text { Esfuerzo de fluencia } \\
\text { Yield Strenght (Kg/mm2) }\end{array}$ & $\begin{array}{l}\text { Carga de Fluencia } \\
\text { Yield Load (Kg) }\end{array}$ & $\begin{array}{c}\text { Esfuerzo Máximo } \\
\text { Maximum Stress } \\
(\mathrm{Kg} / \mathrm{mm} 2)\end{array}$ & $\begin{array}{c}\text { Carga Máxima } \\
\text { M aximum Load (Kg) }\end{array}$ & $\begin{array}{l}\text { Alargamiento M edido } \\
\text { M easured extension }\end{array}$ & $\begin{array}{l}\text { Módulo de Elasticidad } \\
\text { Elasticity Modulus } \\
\text { (Kg/mm2) }\end{array}$ \\
\hline 1 & 35 & 33683 & 48.8 & 46406 & 30 & 1936491 \\
\hline 2 & 40.3 & 20371 & 52.3 & 26355 & 27.5 & 2020294 \\
\hline 3 & 35.9 & 32608 & 49.7 & 45370 & 31 & 2276623 \\
\hline 4 & 36.4 & 32524 & 49.8 & 44188 & 29 & \\
\hline 5 & 40.6 & 18750 & 52.5 & 24171 & 28.5 & 1852156 \\
\hline 6 & 41.5 & 19715 & 53 & 25103 & 27 & \\
\hline Promedio & 38.3 & & & & & 2021391.0 \\
\hline
\end{tabular}

\subsection{Study on local effects}

The seismic threat and dynamic response assessments were conducted at the viaduct job site. Such assessments facilitated the identification of soil and topography effects on the job site, in combination with viaduct's geometry, that in this case are quite important because of material different nature, i.e, the bride piles are significantly long and the viaduct itself has a huge longitude. In order to analyze this specific item, the expected seismic thread was studied for the job site, in order to identify seismic records quite representative for responses analysis. For developing a reliability analysis it was necessary to count with probabilistic seismic thread values. Such values allow the assessment of thread spectrums at standard acceleration speeds or displacements. On the other side, to develop the studies on local responses it is necessary to count with accelerograms quite representative for seismic threat. 
Probabilistic acceleration, speed and displacement spectrums can be made by means of different procedures. In this case, the procedure for calculating spectrums based on threats was used, not only for peak acceleration at the job site, but also for different spectrum sequences, independently. This method, based on ideas introduced by Johnson (1973) and MacGuire (1977), require the presence of attenuation equations not only for peak acceleration at the job site, i.e. zero periods, but also for each one spectrum sequences to be analyzed. Clearly, it allows the assessment of spectrum sequences at an equal threat level, i.e, the same exceeding probability. Assessed spectrums under the third methodology are known under the name of standard thread spectrums.

The seismic model employed by this study was drawn from the O verall Study on Seismic Thread of Colombia (IN GEO MIN AS-UNIANDES, 1996). So as to conduct the threat analysis, a $200 \mathrm{~km}$ radius-circularinfluence zone was studied, which is centered at the Cesar $\mathrm{G}$ aviria Viaduct, and which geographic coordinates are $75.6864 \mathrm{~W}$ and $4.8166 \mathrm{~N}$. Inside the influence zone there are 10 seismogenic sources, 9 out of them simulate line sources and one of them is represented as a circular area having the same events generation probability, the so called "N one source". The identified sources were: intermediate Bennioff, deep Benioff, Cauca, Frontal, Garrapatas, Ibagué, Murindó-A trato, Palestina, Romeral, Salinas and None Source.

By using the spectrum generation software, developed by Eng. Jorge Alonso Prieto, nine (9) different responses spectrums were determined. This software was based on some variation parameters of attenuation equations, defined by geology, main distances from geological fractures in the region, and by data obtained from seismic events recorded by different gauge-meters allocated near the zone. The software was used by introducing the attenuation equation (Ambrasseys et al 2000), thus determining the absolute acceleration for different spectrum periods, varying from zero up to 2 seconds. Furthermore, the yearly exceeding frequency for a seismic event defined by such response spectrum is taken into account (i.e. the reverse mathematic of return period for a seismic event defined by such response spectrum). It solves and assesses the integral given by equation (1), numerically. 
For the actual case, the function of seismic threat density was considered depending on the spectral acceleration sa $(T)$, distance from the job site $r$, and magnitude $m$. Therefore, density function is sa(T). Therefore, and similar to the unidimensional case, the probability of exceeding a spectral acceleration value for the seismic source $i$, is:

$$
P(S A \geq s a)_{i}=\int_{s a}^{s a \max } \int_{m o}^{m u} \int_{r o}^{r \max } f(s a, r, m) d r d m d s a
$$

Following conditional probability properties, the joint density function of acceleration variables, magnitude, radius $f(S a, m, r)$ can be replaced by the product between acceleration conditional density function given a radius and magnitude $f(S a / r, m)$, the function conditional probability of density function given a magnitude $\mathrm{f}(\mathrm{r} / \mathrm{m})$ and density function of yearly magnitude probability $f(m)$. Therefore, equation (1) will be:

$P(S A \geq s a) \sum_{l-1}^{n} P(S A \geq s a)_{i}=\sum_{I-1}^{n} \int_{m o}^{m \max } \int_{r o}^{r \max } P(S A \geq s a / r, m) f(m) d r d m$

$f(m)$ is given by:

$$
f(m)=v_{0} \frac{\beta \mathrm{e}^{-\beta(m-m o)}}{1-\mathrm{e}^{-\beta(m u-m o)}}
$$

Where $v_{0}, \beta$ and $m_{u}$ are characteristic parameters of each fracture system (IN GEO M INAS Y UN IANDES, 1996) and $\mathrm{m} 0$ is the minimum considered magnitude. For the evaluation of $f(r / m)$, relations provided by Wells and Coppersmith (1994) were used, which relate fracture length provided a magnitude, and it depends on the kind of seismic source analyzed (lineal, circular).

The conditional exceeding probability of spectral acceleration for a specific period given radius and magnitude $P(S A \geq s a / r, m)$ of Equation 1, is evaluated by means of the aforementioned attenuation equation. 
Where SA (T)/g is T period's spectral acceleration, expressed by a fraction of $\mathrm{g}$. gravity acceleration. The constants $\mathrm{C} 3$ and $\mathrm{C} 4$ reflect mechanical attenuation due to tensile strength and geometrical attenuation due to distance, respectively. Value $d$ is Joyner and Boore's value, i.e. the distance from the job site up to the horizontal projection surface nearest to the fracture. $M$ is magnitude, $\mathrm{C} 1$ and $\mathrm{C} 2$ are constants; $\mathrm{h}$ is an adjustment parameter; C5 and C 6 are constants defining type of soil in the project; and finally $\mathrm{s}$ is the standard deviation of the equation adjustment, which provides the exceeding probability limit. It should be noted that $\lambda$ takes -1 value for a $16 \%$ exceeding probability, value 1.3 for $10 \%$ and so on. The aforementioned equation, therefore, provides conditional exceeding probabilities for each spectral sequence, period $\mathrm{T}$, provided the magnitudes, distances and type of soil.

Assessment intervals of provided functions in the aforementioned integral were: for radius, the corresponding to length intervals minor than $10 \mathrm{~km}$, measured within the fracture. Intervals magnitude: 0.5 magnitude units. The software settles a value for spectral acceleration and it calculates the probability and the corresponding return period. Therefore, in order to find spectral sequences for different return periods, iteration tests must be made. Input data on standard rock threat (gravity acceleration and periods timed in seconds) for different return periods and a $5 \%$ damping in relation to the critic period, are shown in Figure 3.

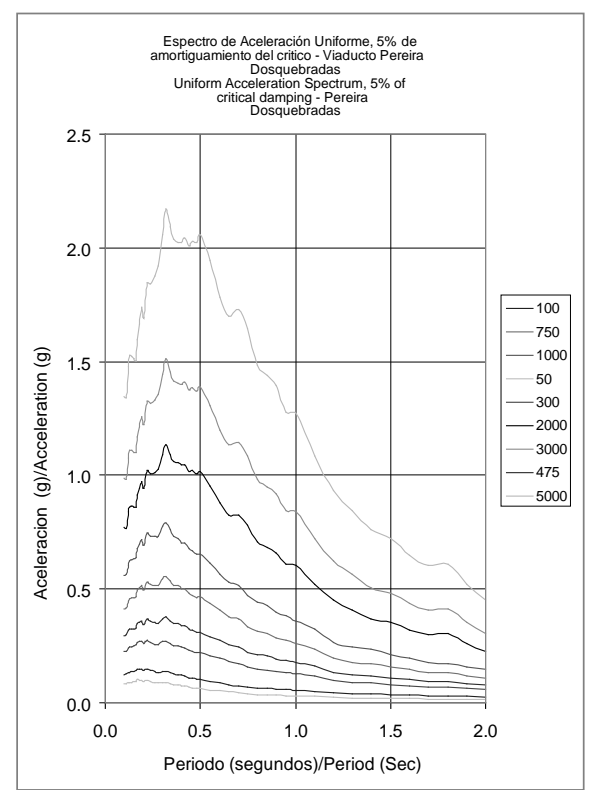

Figura 3. Espectros de respuesta para diferentes periodos de retorno Figure 3. Spectral Response for different return periods 
In order to study the dynamic behavior of soil where the bridge is founded, a geophysical exploration was conducted by means of seismic refraction and D own Hole trial tests (see results in Figure 4, Figure 5 and Table $3)$, thus identifying the rocks depth, probable rock hardness, contact arrangement between layers, continuity or discontinuity of the representative model, compressive speeds, shear speeds, subsoil modules at small strain strength, elastic modules well known as Young (E) module, and maximum shear module $\left(G_{0}\right)$, volumetric strain module $(\mathrm{K})$ and Poisson's relation. Finally correlations between obtained speeds and local geology were also identified. In accordance with the seismic refraction tests, it was found that compressive speed varies in 254-445 $\mathrm{m} / \mathrm{s}, 525-916 \mathrm{~m} / \mathrm{s}$ and $740-1667 \mathrm{~m} / \mathrm{s}$, for stratus 1,2 and 3 , respectively. It means that the first set of layers corresponds to active layers, the second to easydetensioning soils, and the third to easy-difficultydetensioning soils.

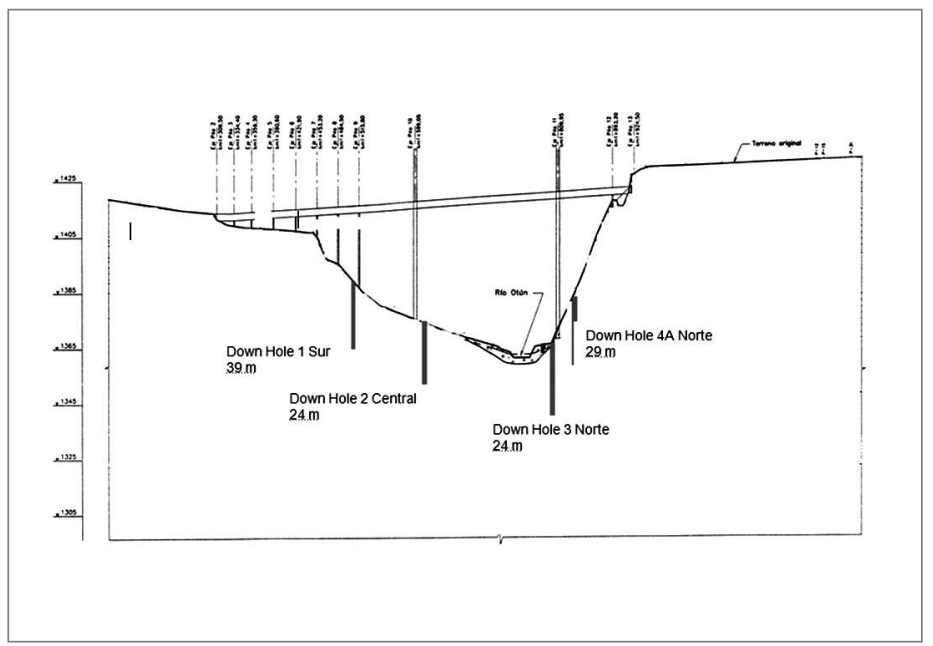

Figura 4. Localización y Nomenclatura Ensayos D own Hole Figure 4. Location and Nomenclature for Down Hole's Trial Tests 


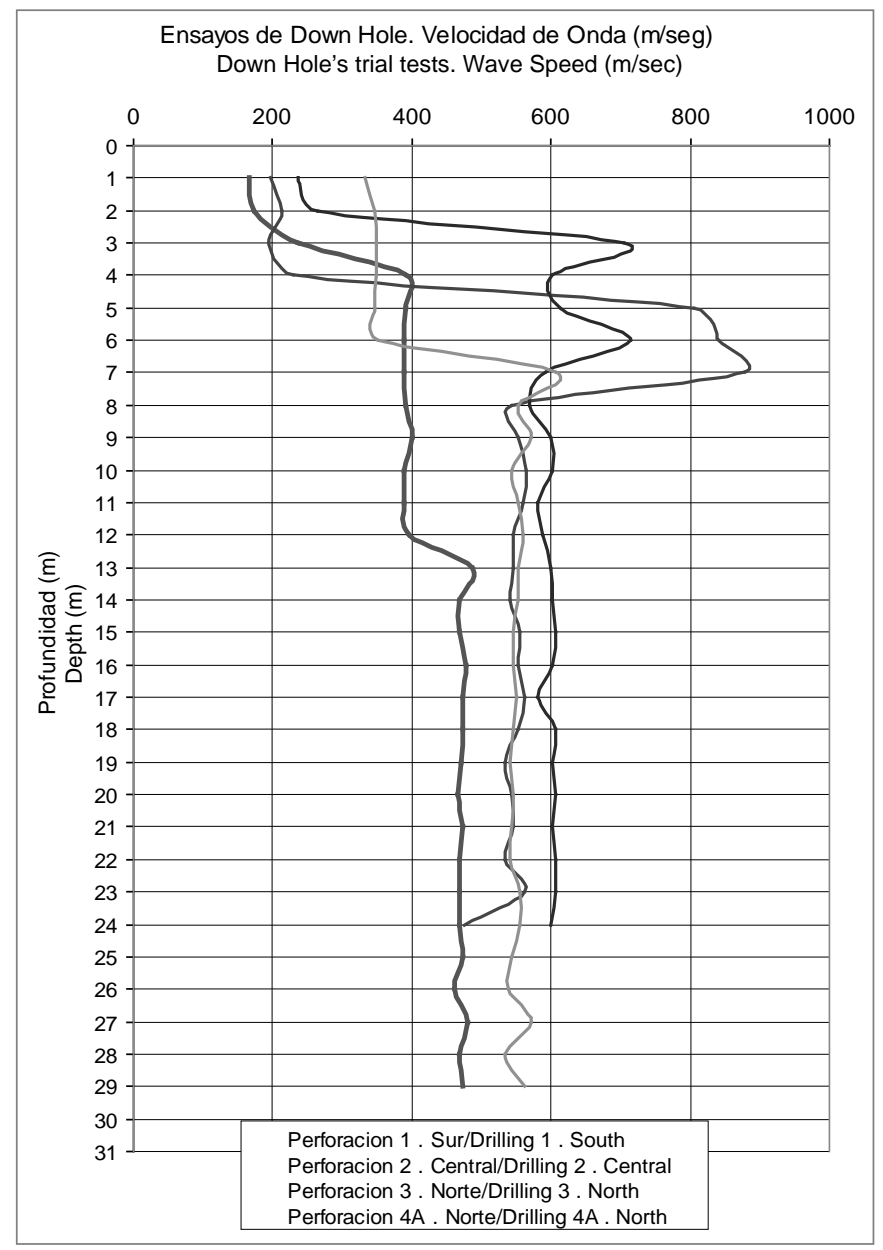

Figura 5. Registros de los Ensayos de Down Hole Figure 5. Records of D own Hole's Trial Tests

Tabla 3. Valores de Velocidad de 0 nda de Corte utilizados en el análisis bidimensional Table 3. Values of Shear Wave Speed used by two-dimensional analysis

\begin{tabular}{|l|c|c||}
\hline Material tipo/Layer Type & Vs (m/s) & Vp (m/s) \\
\hline Aluvión 1/Alluvium Type 1 & 150 & 280 \\
\hline Aluvión 2/Alluvium Type 2 & 175 & 330 \\
\hline Cenizas Volcánicas 1/Volcanic Ash Type 1 & 180 & 340 \\
\hline Cenizas Volcánicas 2/ Volcanic Ash Type 2 & 202 & 378 \\
\hline Depósitos Piroclásticos 1/Pyroclastic deposit Type 1 & 590 & 1080 \\
\hline Depósitos Piroclásticos 2/ Pyroclastic deposit Type 1 & 800 & 1500 \\
\hline
\end{tabular}


Selection of earthwakes to be analyzed considered seismic events that had been identified as representative for the job site seismic threat, by considering the events corresponding to seismic design in accordance with the NSR 98. Representative seismic sources were identified, as well as possible earthwakes in terms of magnitude and distance, which might be expected for the job site as seismic design. Based on such analysis a series of records were identified, which were used to analyze the bridge responses. The geometry is shown below as well as material arrangement and molded grid for finite elements. For analysis, dynamical properties were employed, which resulted from geophysical tests conducted for low strain strength, app. $10^{-6}$ and $10^{-4} \%$, by means of elastic responses analysis. The possible variation of shear strength module and damping at strain strength were not considered, since found materials cannot be classified into soils, even though they may show some stiffness degradation with strain strength due to high intensity earthwakes, this is not the expected condition for a intermediate seismic threat zone. On the other hand, it is not possible to obtain samples or performing representative tests on these kinds of materials in order to assess stiffness variation or depth damping. Finally, by comparing the elastic behavior with low strain strength modules, the most critic behavior condition is being considered as far as acceleration, and therefore, inertial forces are concerned.

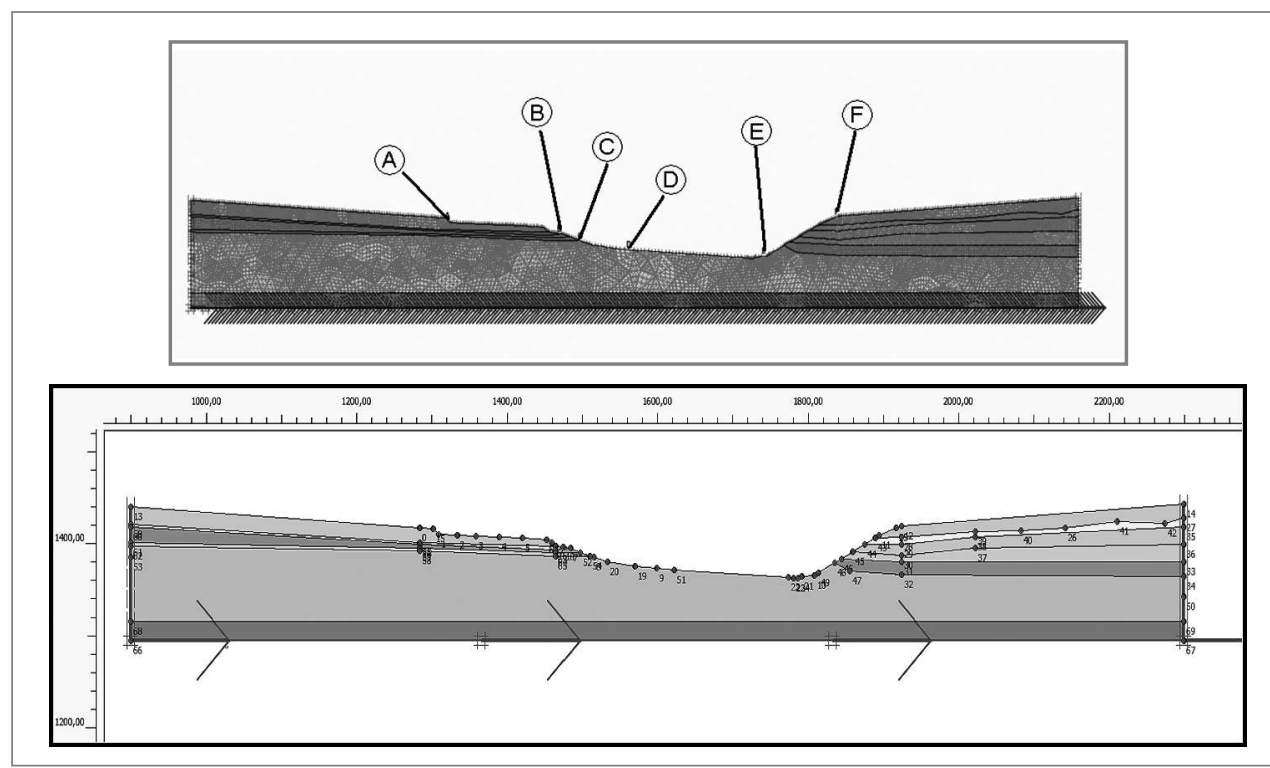

Figura 6. Sección de análisis - sección transversal. Arriba: Zonas de Análisis. Abajo: Malla de elementos finitos Figure 6. Analysis section - transverse section. Above: Analysis Zones. Below: Finite elements' grid 
For seismic response analysis, bidimensional wave spread analysis was made by using the V.8.0 PLAXIS Professional software. This is one of the most advanced finite models for geotechnical analysis available now adays. The software allows the performance of elastoplastic analysis using different soils behavior models, at arbitrary construction and load sequences including structural elements. Solid elements are molded by triangular isoparametric elements of 6 or 15 knots. For dynamical analysis the software uses the Newmark's implicit unconditional converging scheme, which is integrated step by step overtime. Damping is calculated based on the seismic predominant frequency; the range of significant frequencies for analysis and the assumed material damping are used to calculate Rayleigh's damping parameters used by the model. The software has built-in absorption boundaries to avoid the reflection of waves spreading in the model at side boundaries. The earthwake is applied on the model base. Spectral results from acceleration, at selected points, were analyzed thus obtaining a $5 \%$ damping spectrum response by means of DEGTRA 2000 software (O rdaz. M, 2002). Acceleration spectrums for each point at diverse return period values are shown below (Figure 7); these graphs were made by multiplying standard acceleration spectrums by amplification relations obtained from each point. 

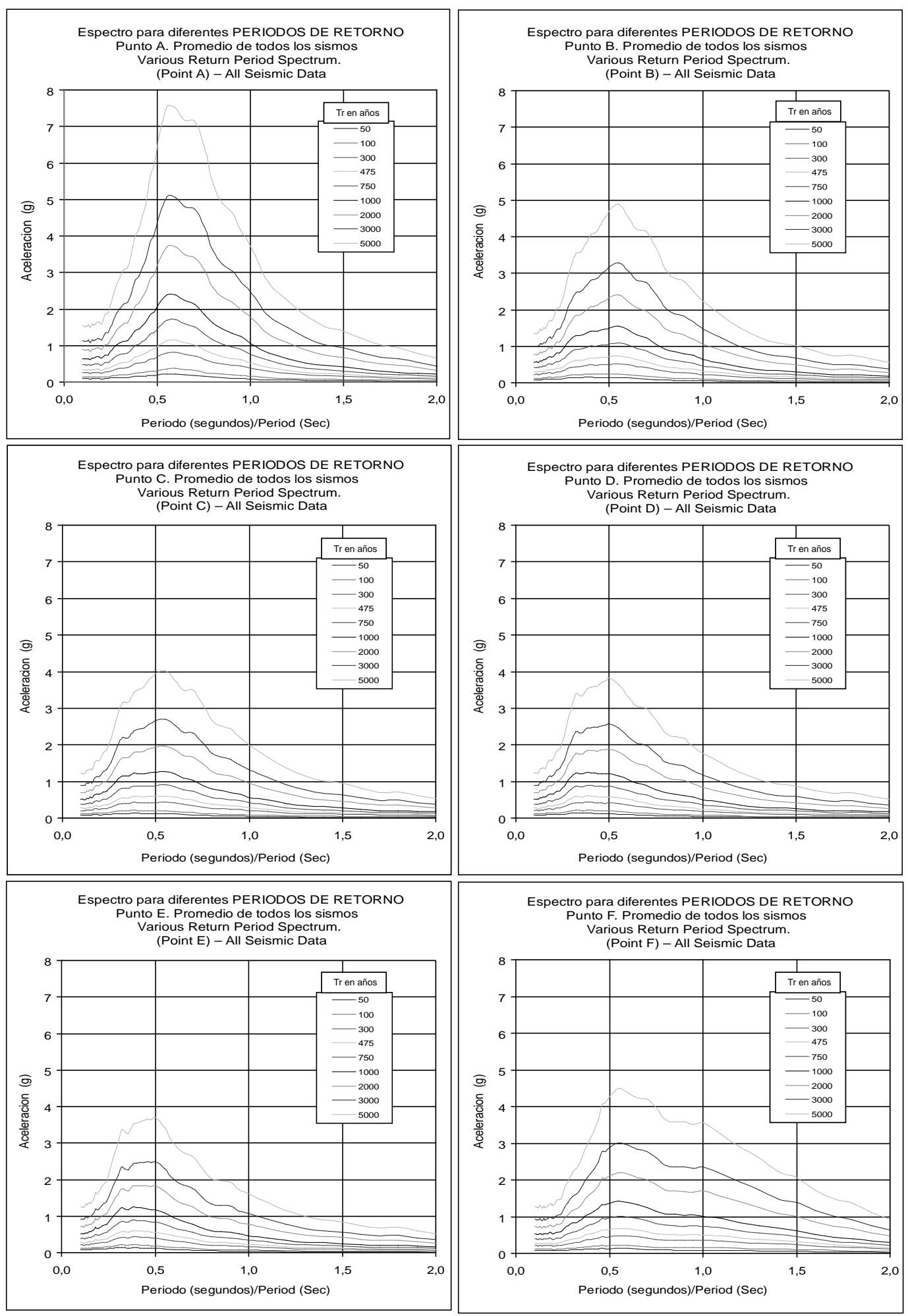

Figura 7. Espectros para diferentes periodos de retorno. Puntos $A, B, C, D, E$ y $F$ correspondientes a los diferentes puntos de pilas y pilones.

Figure 7. Spectrums at different return periods. A, B, C, D, E and F Points correspond to different points of bearing piles and pylons. 
2.3 Development and Calibration of structural model

Two structural models were developed my means of SAP- $2000{ }^{\circledR} \mathrm{S}$ software, which were subject to a calibration process, which is based on a vertical load test and an environmental vibration study.

Structural Model Nr. 1 was employed to build up the timeline at the viaduct construction, and as a tool for determination of record tensile strengths. The concrete plastic flow was taken into consideration because of the prolonged axial load presence in the pylons, during sequence construction of deck bridge slab, and during the whole tightening and re-tightening process of bridge's wire strainers. This model was defined by a total of 1429 knots, 1198 lineal elements FRAME type, 72 lineal elements CABLE type, and 1188 elements SHELL type. Structural Model Nr. 2 facilitated a structural response quite close to pylons local effects, since modeling provided a view of shear effects on walls and slabs belonging to bridge pylons, as well as the shear stress concentration at wire strainers joint zones. This model was defined by a total of 3946 knots, 1131 lineal elements FRAM E type, 72 lineal elements CABLE type and 40936 elements SHELL type.

Both models included abutments in the zones where pylons are connected to the superstructure; in the case of abutment pier closest to Dosquebradas city, the bearings had some unrestricted degrees of freedom, because of the kind of mechanical joint existing in this bridge.

\subsubsection{Static Calibration for vertical loads}

Eight (8) duly weighted dumps and four (4) load hypothesis were used for loading test (see Figure 8). Before setting eight dumps, a topographic measurement on the empty conditions of the bridge was done, in order to compare reference zero spot height by the time the bridge was opened for normal operation in 1998 , to the present zero spot height (2008)

Once reference zero spot height was determined for loading test, strain strengths were registered for four (4) load cases, which were compared to results obtained from structural model Nr. 1. By using the information on loading test, strength parameters in the model were modified, for concrete strength and elasticity module either on pylons and longitudinal slab, as well as fy values for hard steel, some conditions of bearing slab with pylons, in order to obtain acceptable values in the calibration process. 
The following table shows relative errors obtained from one test in two structural models (Test 2). Figure 10 graphically depicts the results of such calibration for hypothesis 2 .

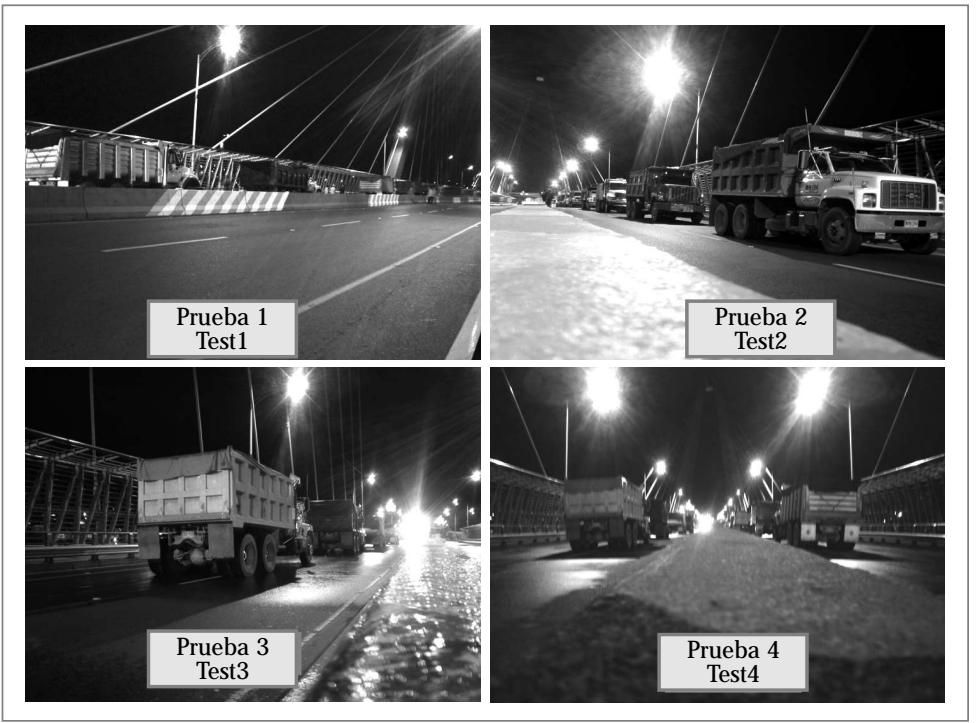

Figura 8. Fotografía de las cuatro (4) posiciones de las volquetas en la prueba de carga. (1) y (2) Excéntrica en el vano lateral y central del lado de Dosquebradas Figure 8. Picture of four (4) dumps positions for loading test (1) and (2) Eccentric stress on side and central span at Dosquebradas wing

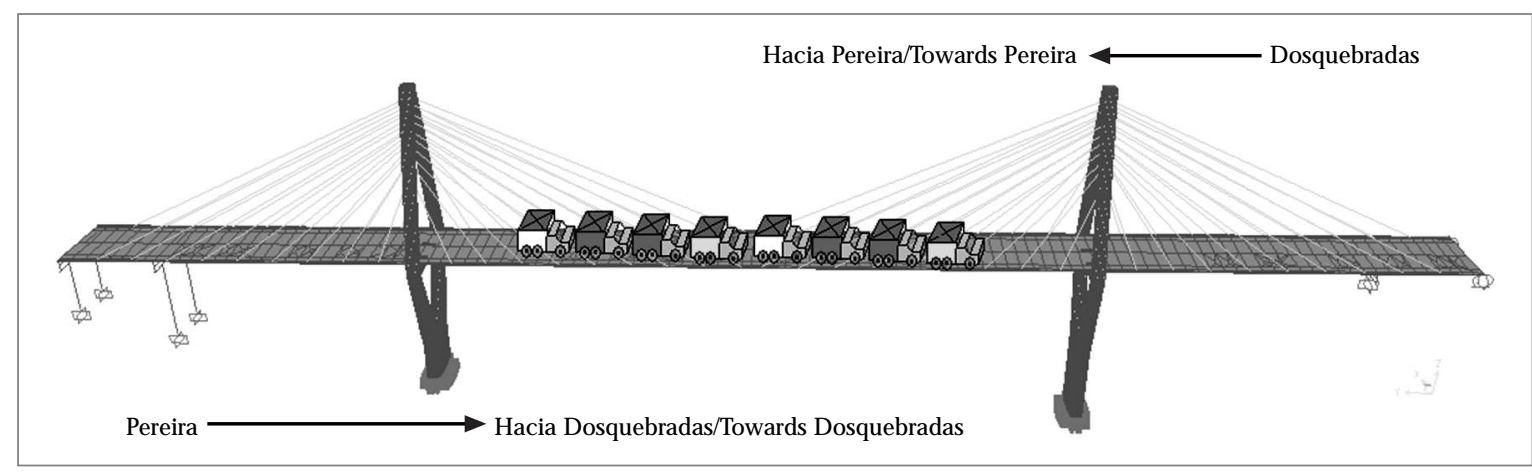

Figura 9. Esquema de localización de las volquetas para la hipótesis 2 en la prueba de carga Figure 9. Dumps Arrangement Scheme, hypothesis 2 during loading test

Tabla 4. Porcentajes de error - Calibración dos modelos estructurales Table 4. Error Percentages - Calibration of two structural models

\begin{tabular}{|c|c|c|c|c|c||}
\hline \multicolumn{2}{|c|}{} & \multicolumn{2}{c|}{ Modelo 1/Model 1 } & \multicolumn{2}{c|}{ Modelo 2/Model 2 } \\
\hline $\begin{array}{c}\text { Zona de Análisis/ } \\
\text { Analysis zone }\end{array}$ & $\begin{array}{c}\text { Medidos (Topografía)/ } \\
\text { Measured (Topography) }\end{array}$ & $\begin{array}{c}\text { Tomado/ } \\
\text { Taken at }\end{array}$ & $\begin{array}{c}\text { Diferencia (\%)/ } \\
(\%) \text { Difference }\end{array}$ & $\begin{array}{c}\text { Tomado/ } \\
\text { Taken at }\end{array}$ & $\begin{array}{c}\text { Diferencia (\%)/ } \\
(\%) \text { Difference }\end{array}$ \\
\hline A & 10.2 & 10.4 & $2 \%$ & 10.24 & $0.4 \%$ \\
\hline B & 13.3 & 16.2 & $37 \%$ & 13.598 & $2.2 \%$ \\
\hline C & 13.2 & 17 & $40 \%$ & 17.02 & $22.4 \%$ \\
\hline Máximo/Maximum \\
Mínimo/Minimum
\end{tabular}

Zona $\mathrm{A}=$ Viga longitudinal lado del puente que va desde Dosquebradas y hacia Pereira/Zone $\mathrm{A}=$ Bridge longitudinal beam in side going from D osquebradas towards Pereira Zona $B=$ Viga longitudinal zona central simétrica del puente/Zone $B=$ Bridge longitudinal beam from symmetric central zone

Zona $C=$ Viga longitudinal lado del puente que va desde Pereira y hacia D osquebradas/Zone $C=$ Bridge longitudinal beam in side going from Pereira towards D osquebradas 

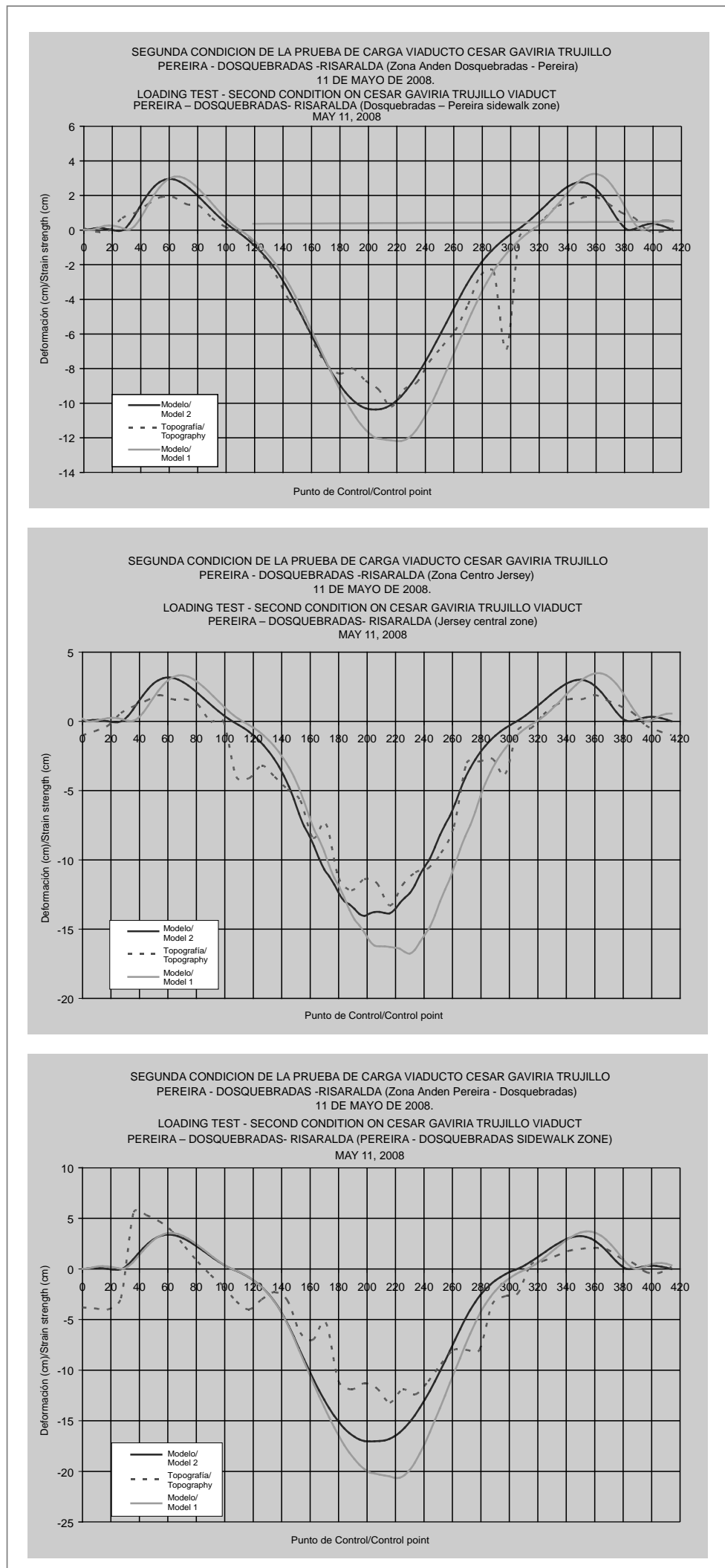

Figura 10. Resultados prueba de carga 2. Diferencias deformación elástica del tablero modelado vs deformaciones registradas en campo del puente en el lado derecho, izquierdo y centro Figure 10. Results for loading test 2. Elastic strain strength differences on deck slab V/S strain strength recorded at the job site on the right-left and center sides of the bridge 
Initially from this job site activity, a horizontal side view was obtained for the bridge's strain strength without any traffic load, where waviness was detected in every single span and also uprising strain strength in the central span of $24 \mathrm{~cm}$ (see Figure 11). Such side view was compared to the one provided by Inventory $M$ anagement by the time the bridge was delivered in 1997, finding a $10 \mathrm{~cm}$ difference, which indicates that the bridge has ceded because different reasons: effects of normal overload and its additional impact, unforeseen loads (safety fences - suicide prevention), wire strainers' tension relief, temperature, among others.

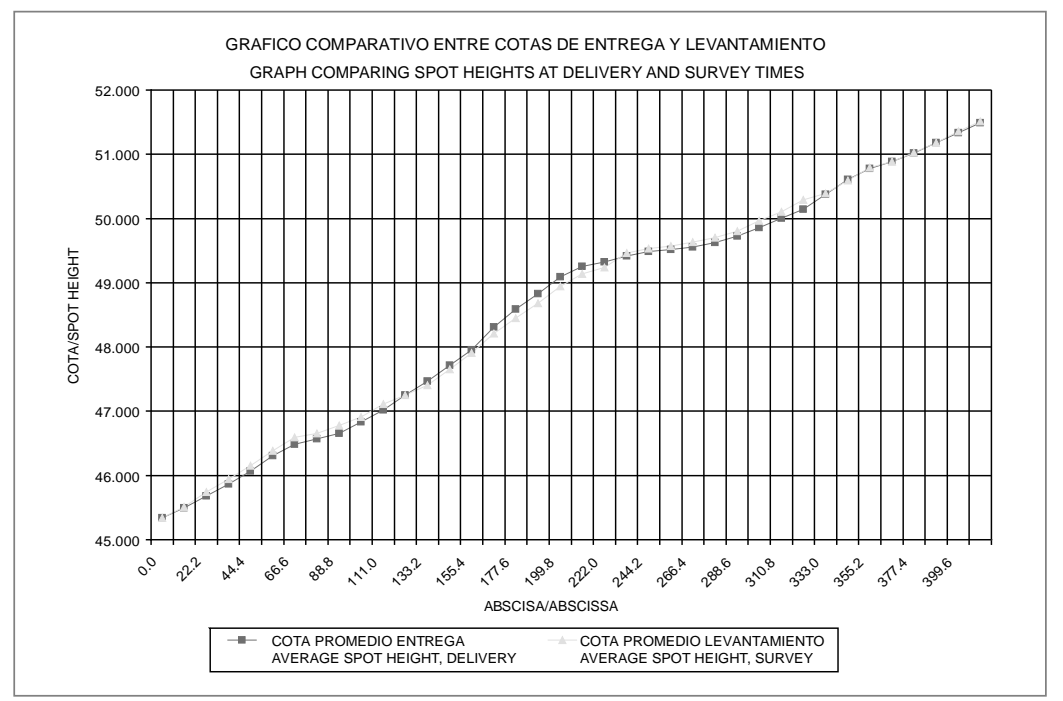

Figura 11. Comparación del perfil de deformaciones para el puente vacío comparadas con el perfil en el momento de la entrega del proyecto (1997)

Figure 11. Comparison of strain strength side view for an empty bridge $\mathrm{v} / \mathrm{s}$ side view at the time the project was delivered (1997)

2.3.2 Calibration for environmental vibrations In order to find the predominant periods and frequencies in the bridge structure, an environmental vibrations study was conducted. Such study did not consider the structure vibration model and the damping percentage, which were scheduled for future researches on this same bridge. There are several researches on this subject, by means of frequency domain methods, such as Peak Picking, FDD Frequency domain decomposition and EDD Enhanced Frequency domain decomposition. Time domain methods were also employed, such as: "Eigensystem Realization Algorithm (ERA)" and "Stochastic Subspace Identification (SSI-DATA)" (See [Gómez A., (2010)]). 
Therefore, the bridge structure was instrumented, by means of three (3) accelerometers type Wilcoxon $731 \mathrm{~A}$, its respective amplifiers and a data collection card. This equipment receives and transmits signals from the accelerometers to a computer, registering data on real time and storing them in text files. Wilcoxon sensors used for this monitoring process have the capacity of collecting 200 inputs per second, and they have an importance frequency range between 0 and $20 \mathrm{~Hz}$.

There are several dynamical studies on bridges, which experince has been quite important and taken into account by this studt, such as: [Gallego M. (2007)], [Sarrazin M. (2000)], [Binaria Ltda. (2006)], [Gómez A. (2010)], [Wei-Xim Ren et al. (2004)], [Randall J. et al. (2003)], [Thomsosn, P. et al. (2003)], among others. In order to determine dynamic properties of this bridge, the following procedure was applied on every single accelerometer signals (accelerograms) by means of a softare developed by MatLab ${ }^{\circledR}$.

- Base line correction for records, which base line, is different to zero.

- The application of Pasabanda digital filter, eliminating noises and adjusting record frequencies into range related to the kind of structure.

- Development of an analysis which enables the conversion of time domain into frequency domain. Above was achieved by using Fourier fast conversion method, which yields Fourier amplitude spectrum for each record. Each one of these amplitude spectrums was softened using sub-routines by MatLab ${ }^{\circledR}$, to avoid Aliasing related to high frequencies. Records were zoomed to a window considered for low frequency of $0.1 \mathrm{~Hz}$ and high frequency of $20 \mathrm{~Hz}$. O btained values out of this range, were discarded.

- Transference functions were determined for each pylon, in order to obtain effective structure vibrations. Those were made by using a ratio between Fourier conversion filtered signals in the tower upper point, and Fourier conversion filtered signals in the foundation.

In order to conduct such experimental activity, accelerometers were arranged as show in the following figure, where transverse vibrations were measured, longitudinally and vertically: 


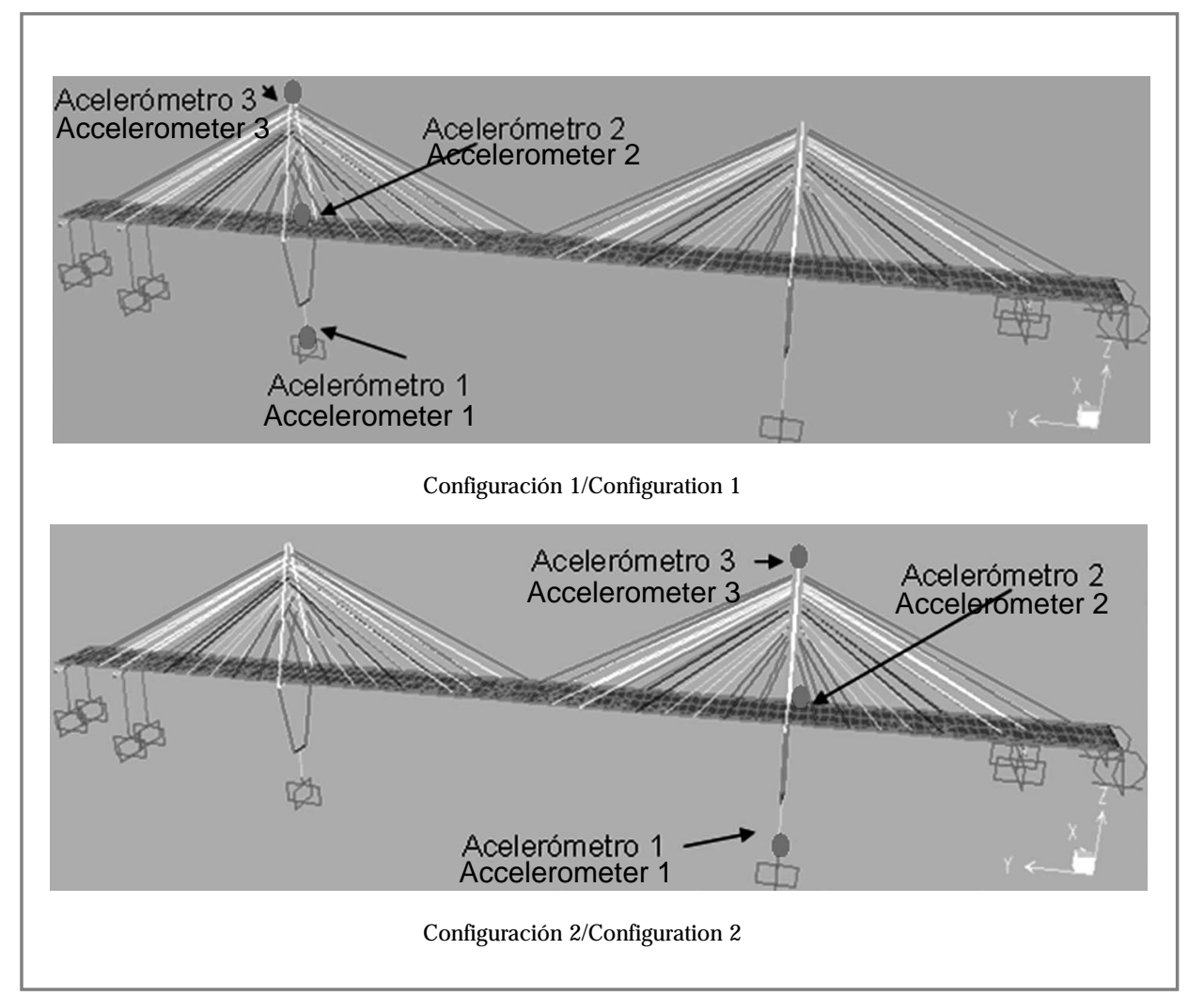

Figura 12. Localización de los acelerómetros para realizar las mediciones ambiéntales en el pilón de Pereira y Dosquebradas. Cota zona superior pilón (3), cota placa estructural (2) y cota zona inferior del pilón (1)

Figure 12. Accelerometers arrangement in order to develop environmental measurements on Pereira and Dosquebradas pylons. Spot height pylon upper zone (3), spot height structural slab (2) and spot height pylon lower zone (1)

Environmental vibrations of Pereira and Dosquebradas pylons are presented below, in transverse direction. 


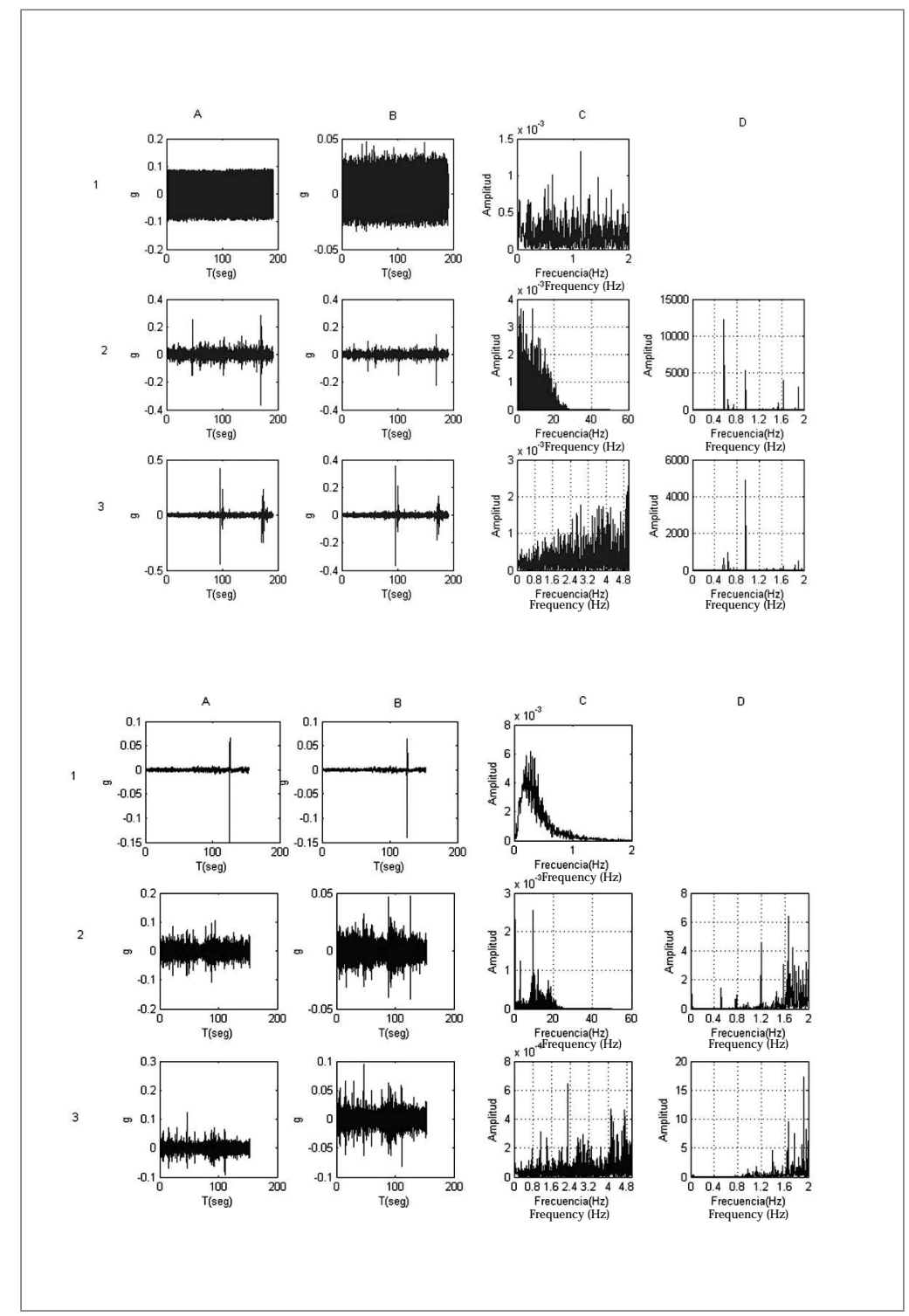

Figura 13. Análisis de vibraciones ambientales del pilón de Pereira y D os Q uebradas en sentido transversal.

(A1) Acelerograma 1 (sin filtrar). (B1) Acelerograma 1 (filtrado). (C1) Transformada de fourier del registro del acelerómetro 1.

(A2) Acelerograma 2 (sin filtrar). (B2) Acelerograma 2 (filtrado). (C2) Transformada de fourier del registro del acelerómetro 2.

(D2) Función de transferencia C2/C1. (A3) Acelerograma 3 (sin filtrar). (B3) Acelerograma 3 (filtrado).

(C3) Transformada de fourier del registro del acelerómetro 3. (D3) Función de transferencia C3/C1

Figure 13. environmental vibration analyses of Pereira and D osquebradas pylons, in transverse direction.

(A1) Accelerogram 1 (not filtered). (B1) Accelerogram 1 (filtered). (C1) Accelerogram register 1 data converted by Fourier method.

(A2) Accelerogram 2 (not filtered). (B2) Accelegrogram 2 (filtered). (C2) Accelerogram register 2 data converted by Fourier method.

(D2) transference function C2/C1. (A3) Accelerogram 3 (not filtered). (B3) Accelerogram 3 (filtered).

(C3) Accelerogram register 3 data converted by Fourier method. (D3) Transference function C3/C1. 


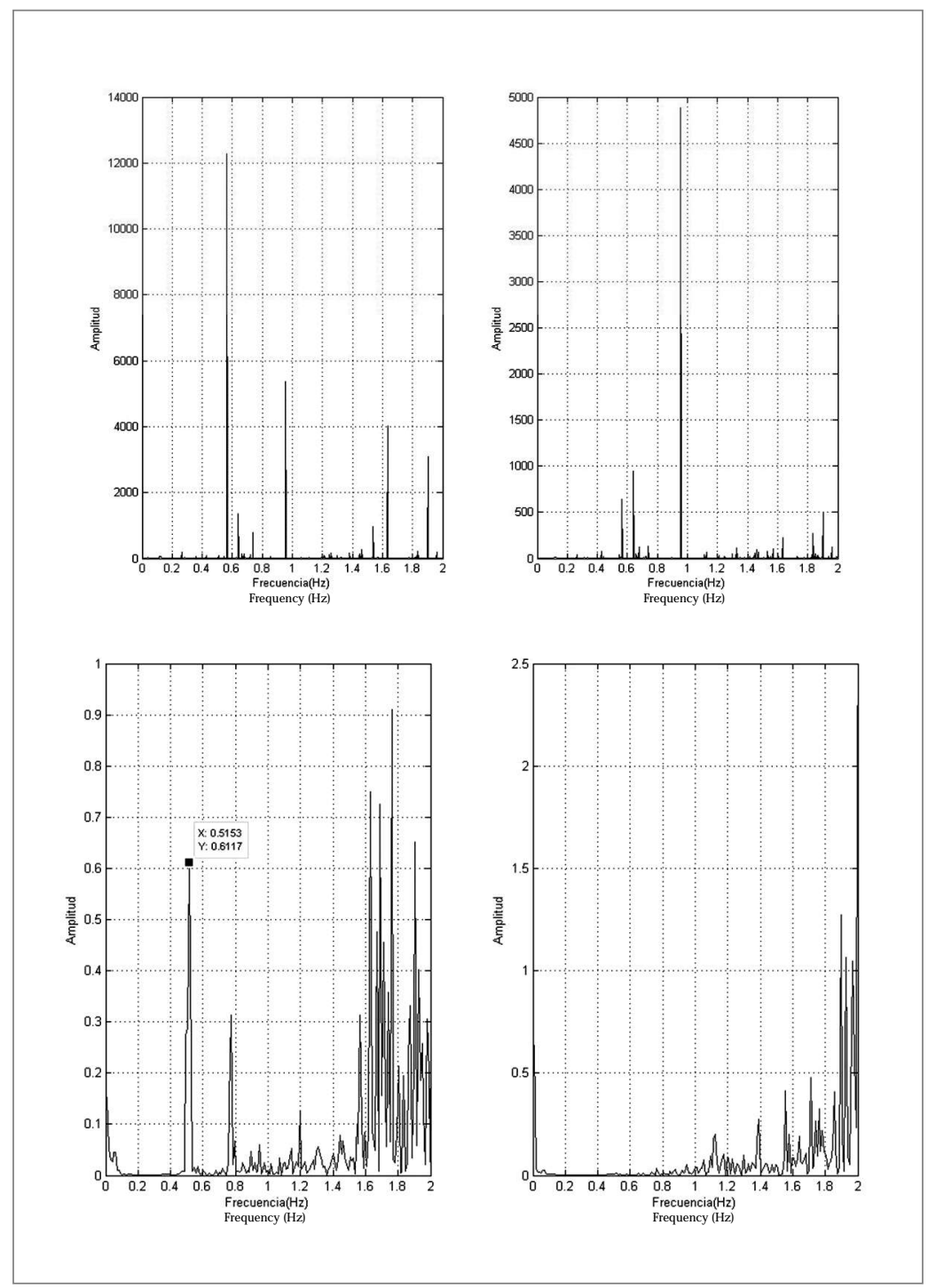

Figura 14. Análisis de vibraciones ambientales del pilón de Pereira (arriba) y D os Q uebradas(abajo) en sentido transversal. Funciones de transferencia en la parte central y superior respectivamente del pilón Figure 14. Environmental vibration analysis conducted on Pereira Pylon (upper) and Dosquebradas pylon (below), in transverse direction. Transference functions of pylon central and upper part, respectively

Tabla 5. Resultados de las frecuencias y periodos de vibración registradas en campo para los dos (2) pilones del Viaducto Cesar Gaviria Table 5. Frequency results and vibration periods recorded at the job site for both (2) pylons of Cesar Gaviria Viaduct

\begin{tabular}{|c|c|c|c|c|}
\hline \multicolumn{5}{|c|}{ Pilón/Pylon } \\
\hline & \multicolumn{2}{|c|}{ Pereira } & \multicolumn{2}{|c|}{ Dosquebradas } \\
\hline & Frecuencia $(\mathrm{Hz}) /$ Frequency $(\mathrm{Hz})$ & Periodo(Seg)/Period (sec.) & Frecuencia(Hz)/Frequency $(\mathrm{Hz})$ & Periodo(Seg)/Period (sec.) \\
\hline 1 & 0.56 & 1.79 & 0.51 & 1.96 \\
\hline 2 & 0.64 & 1.56 & 0.77 & 1.30 \\
\hline 2 & 0.95 & 1.05 & 0.97 & 1.03 \\
\hline
\end{tabular}


Las vibraciones ambiéntales de los pilones de Pereira y Dosquebradas en sentido Iongitudinal se presentan en las figuras a continuación.
Environmental vibrations of Pereira and Dosquebradas pylons, in longitudinal direction are shown below:
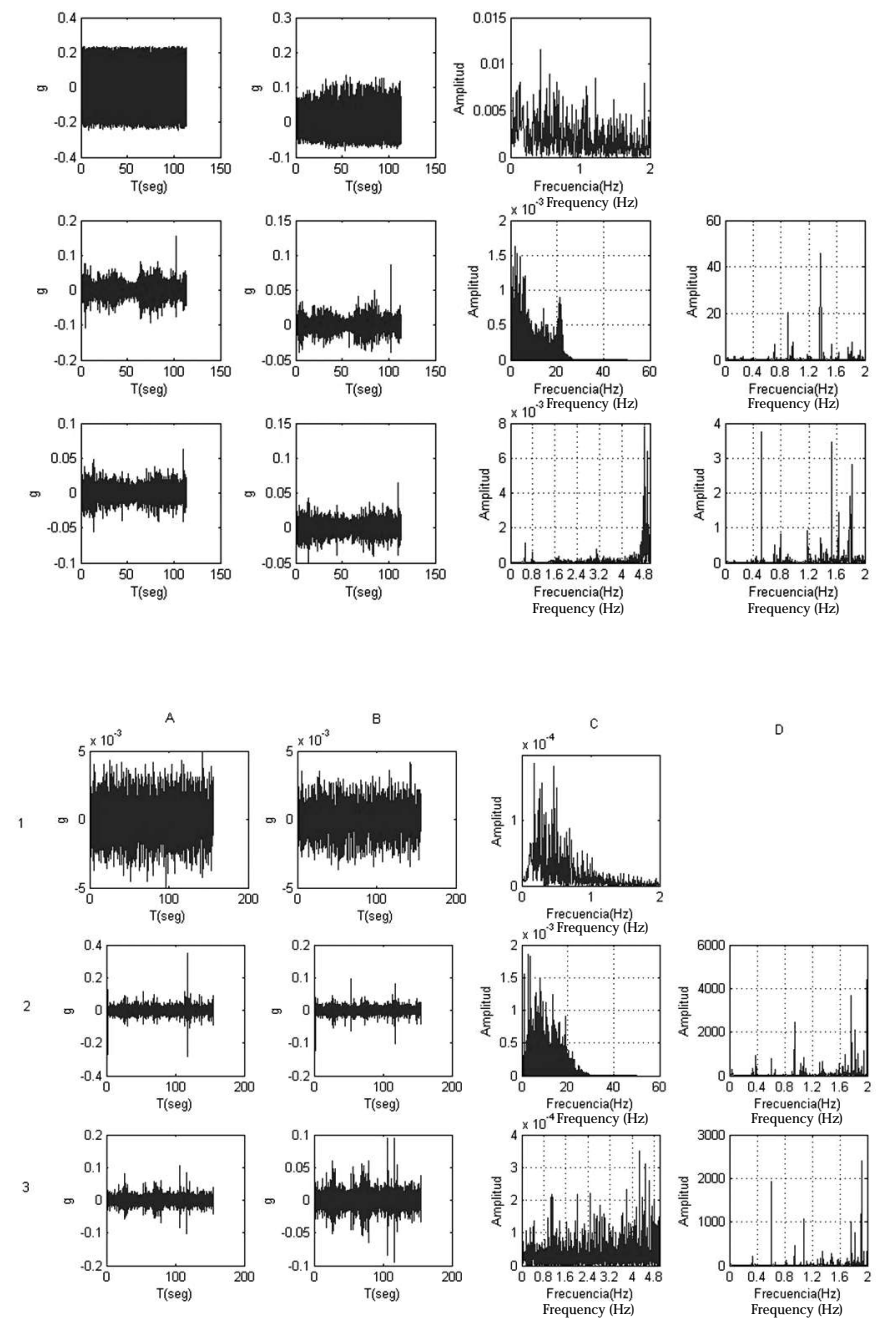

Figura 15. Análisis de vibraciones ambientales del pilón de Pereira y Dos Q uebradas en sentido longitudinal. A1) Acelerograma 1 (sin filtrar). (B1) Acelerograma 1 (filtrado). (C1) Transformada de fourier del registro del acelerómetro 1 (A2) Acelerograma 2 (sin filtrar). (B2)

Figure 15. Environmental vibration analyses of Pereira and Dosquebradas pylons, in longitudinal direction. (A1) Accelerogram 1 (not filtered). (B1) Accelerogram 1 (filtered). (C1) Accelerogram register 1 data converted by Fourier method. (A2) Accelerogram 2 (not filtered). (B2) 


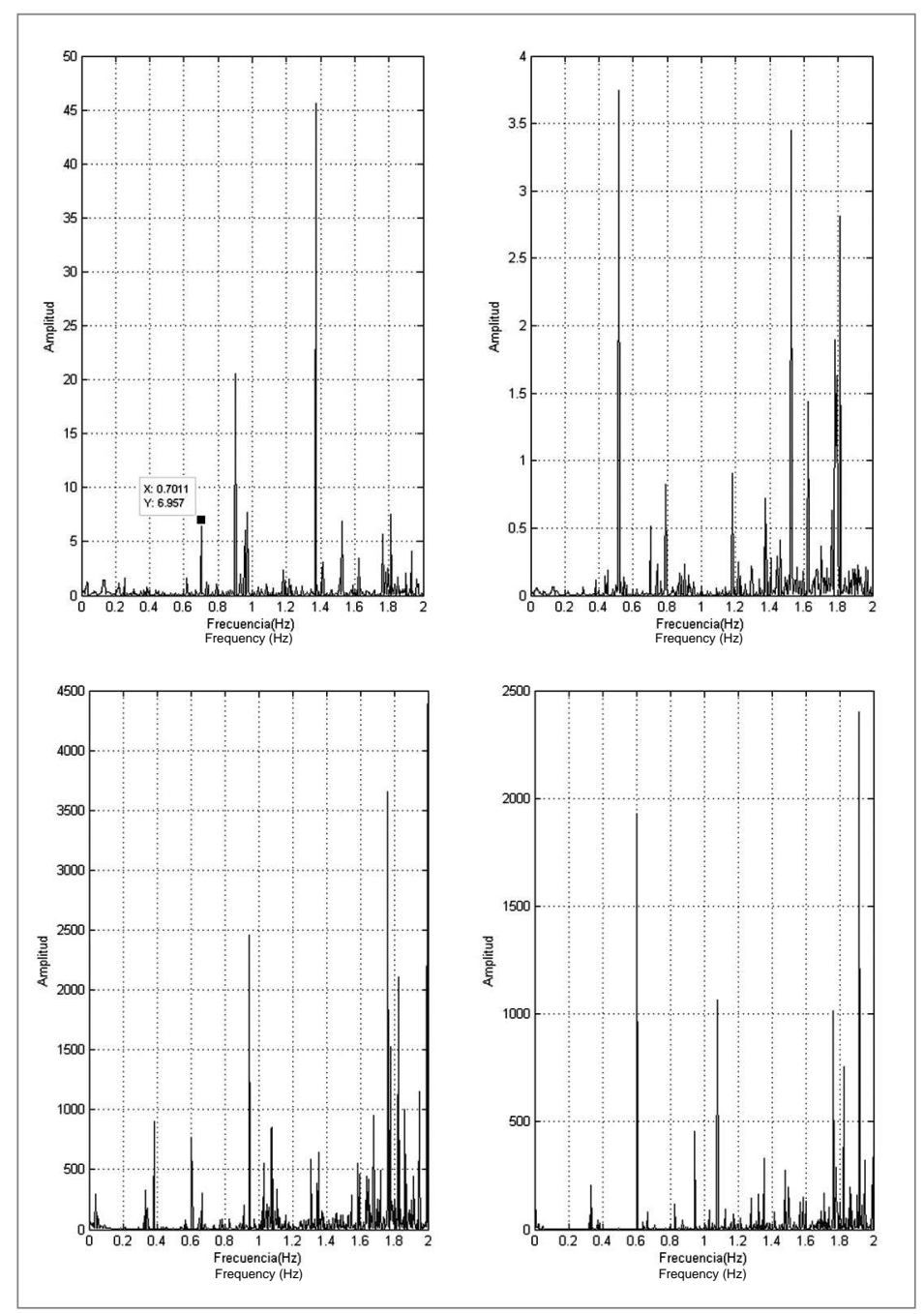

Figura 16. Vibraciones ambientales del pilón de Pereira y Dos Q uebradas en sentido Iongitudinal Figure 16. Pereira and Dosquebradas Pylons - Environmental vibrations in longitudinal direction

Tabla 6. Resultados de las frecuencias y periodos de vibración de los dos (2) pilones Table 6. Frequency results and vibration periods recorded at the job site for both (2) pylons

\begin{tabular}{|c|c|c|c||}
\hline \multicolumn{2}{|c|}{ Pilón de Pereira/Pereira Pylon } & \multicolumn{2}{c|}{ Pilón de Dosquebradas/ Dosquebradas Pylon } \\
\hline Frecuencia(Hz)/Frequency (Hz) & Periodo(Seg)/Period (sec.) & Frecuencia(Hz)/Frequency (Hz) & Periodo(Seg)/Period (sec.) \\
\hline 0.700 & 1.429 & 0.380 & 2.632 \\
\hline 0.890 & 1.124 & 0.940 & 1.064 \\
\hline 0.970 & 1.031 & 1.070 & 0.935 \\
\hline 1.370 & 0.730 & & \\
\hline
\end{tabular}


By using this experimental information, a calibration on structural model number 1 was made, by means of geometry adjustment and material properties based on trial tests (elasticity module, etc.), mass review, and studies on bearing conditions, among others. For the first four (4) vibration modules on structural model the following calibration levels were obtained:

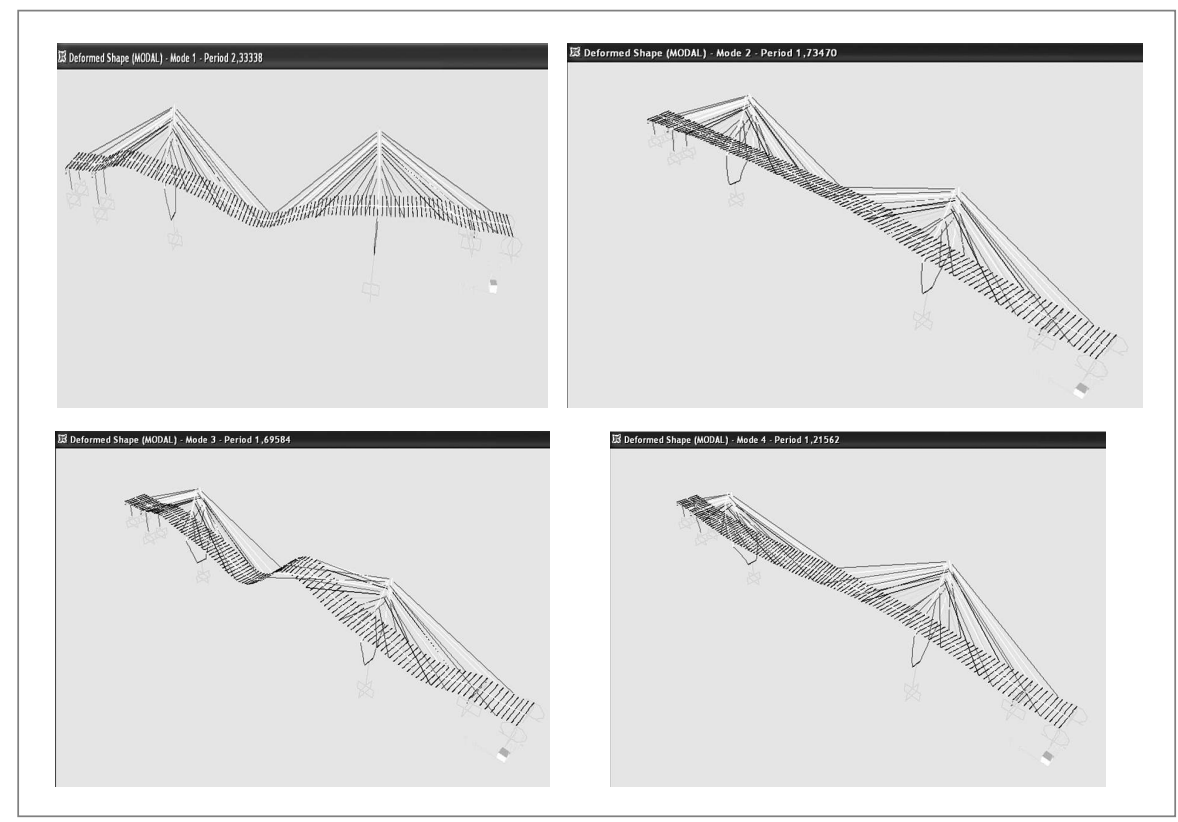

Figura 17. (a) Primer modo de Vibración - Sentido Longitudinal (b) Segundo Modo de Vibración - Sentido Transversal.

(c) Tercer Modo de Vibración - Sentido Longitudinal. (d) Cuarto Modo de Vibración - Torsional

Figure 17. (a) First vibration module, Iongitudinal direction (b) Second vibration module, transverse direction.

(c) Third vibration module - Iongitudinal direction. (d) Fourth vibration module, torsion strength

Tabla 7. Niveles de calibración del modelo estructural

Table 7. Calibration levels for the structural model

\begin{tabular}{|c|c|c|c|c|c|c|}
\hline & \multirow[b]{2}{*}{$\begin{array}{c}\text { Periodos predominantes } \\
\text { identificados en campo (seg) } \\
\text { Predominant periods in the } \\
\text { field (sec) }\end{array}$} & \multicolumn{4}{|c|}{$\begin{array}{l}\text { Periodos obtenidos del modelo estructural (Seg) } \\
\text { Periods obtained from the structural model (Sec) }\end{array}$} & \multirow[b]{2}{*}{ Descripción/D escription } \\
\hline & & $\begin{array}{l}\text { Peso específico concreto } \\
\text { Specific weight of concrete } \\
\mathrm{fc}=2.65 \text { ton } / \mathrm{m} 3\end{array}$ & Error & $\begin{array}{l}\text { Peso específico concreto } \\
\text { Specific weight of concrete } \\
\text { fc }=2.65 \text { ton } / \mathrm{m} 3\end{array}$ & Error & \\
\hline \multicolumn{7}{|c|}{ Modo/Mode } \\
\hline 1 & 2.63 & 2.33 & $11 \%$ & 2.34 & $11 \%$ & Sentido Iongitudinal/Longitudinal direction \\
\hline 2 & 1.79 & 1.73 & $3 \%$ & 1.78 & $1 \%$ & Sentido transversal/Torsional direction \\
\hline 3 & 1.56 & 1.69 & $8 \%$ & 1.7 & $9 \%$ & Sentido longitudinal/Longitudinal direction \\
\hline 4 & 1.05 & 1.21 & $15 \%$ & 1.26 & $20 \%$ & Torsional/Torsion strenght \\
\hline
\end{tabular}


2.4 Monitoring process and instrumentation A wireless monitoring system was designed, which was used to follow up the normal overload effects on five (5) major bridge elements. The bridge elements selected for monitoring activity are shown in the figure below:

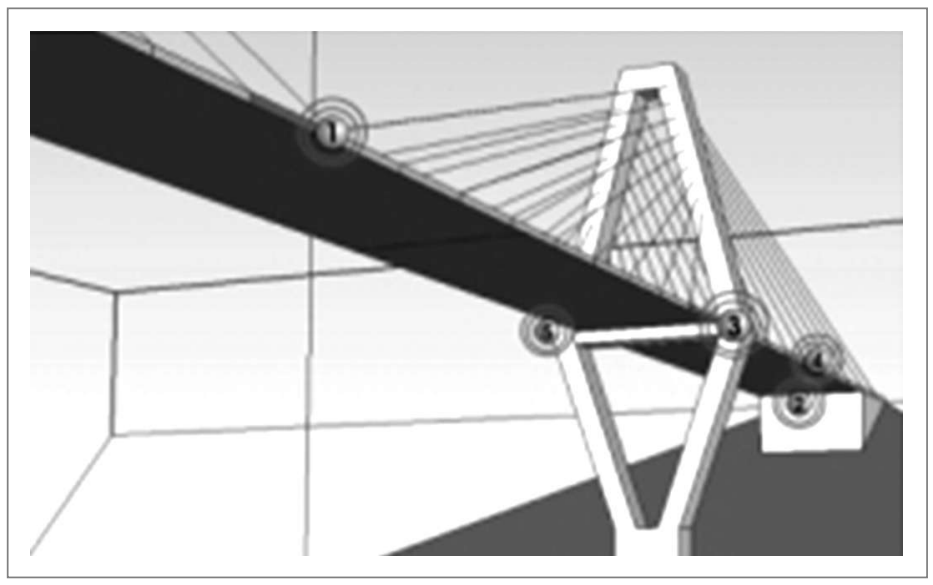

Figura 18. Localización de los elementos que fueron monitoreados Figure 18. Location of monitored elements

Location of monitored elements complied with previous research on maximum stress strength registered on the metal structure, in accordance with the bridge typology. Each node has two (2) strain gauges connected. O btained measure from two (2) strain gauges is processed by the sensor node to obtain unit strain strength, which is further converted into stress strength. Measure is wirelessly transmitted to data concentrator, by means of Zigbee modules (transmitting on radio sequence). Nodes' current supply is provided by a solar cell panel and a battery. The concentrator receives wireless information from sensor nodes. It gathers stores and transmits data through an Ethernet port, under TCP/IP protocol. This concentrator has been programmed as a web server, duly protected by a password, and it has a TCP/IP socket server holding for clients. Web server allows access, through internet explorer, to configuration and diagnoses data from concentrator circuit. The software is protected by user name and password, so that only the administrator is able to handle configuration variables of the system. W imax ${ }^{\circledR}$ modem is an appliance that enables wireless connection to Internet. A Wimax $®$ modem was connected to the concentrator to provide internet access. 
After its configuration is completed, any internet connected computer may access the concentrator, so as to receive measurements from sensor nodes. IP video cameras provided video-real time-streaming through internet. Two (2) cameras were installed at Pereira pylon, 50 meters above bridge deck, in order to offer an overall perspective of traffic activity and analyze it, in parallel, with data obtained by sensor nodes. (See Figure 19 up to Figure 21).

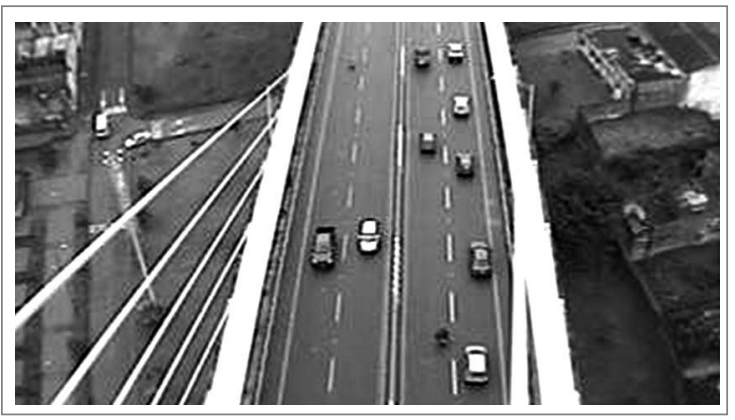

Figura 19. Video del tráfico de cámara 1, de luz lateral hacia D os quebradas Figure 19. Traffic's video streaming, camera 1 , side span towards D os quebradas

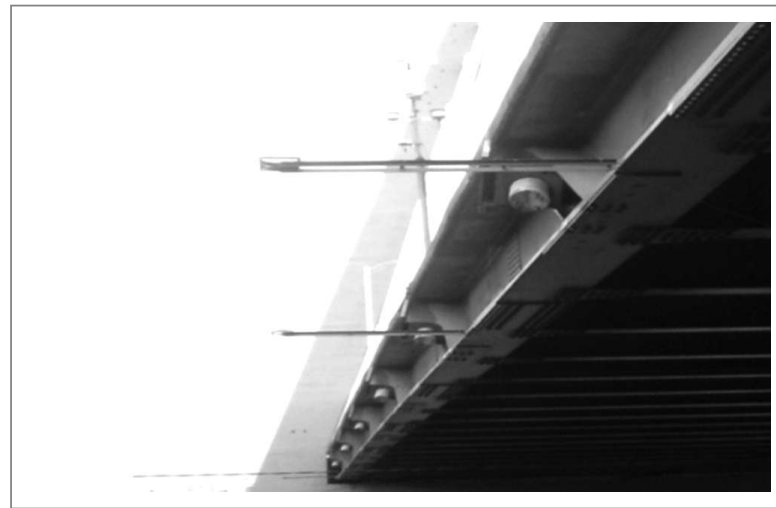

Figura 20. Sistema de soporte para colocación paneles solares Figure 20. Bearing system to install solar cell panels

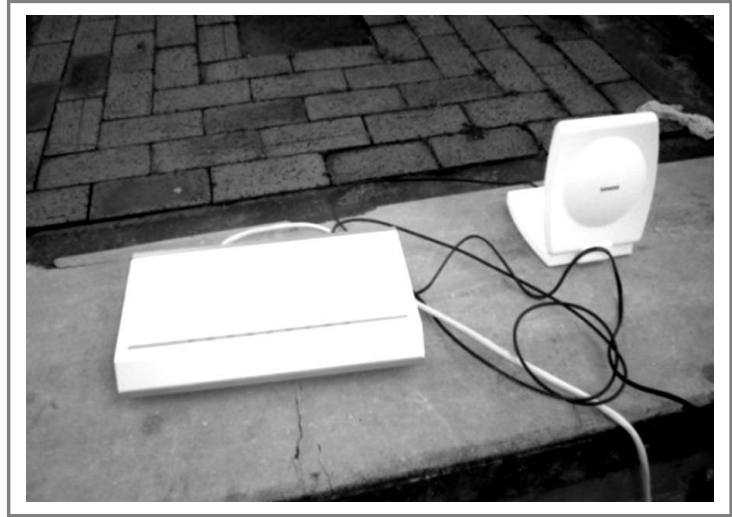

Figura 21. Sistema Satelital Local de Señal + LAN Wireless Figure 21. Signal local satellite system + Wireless LAN 


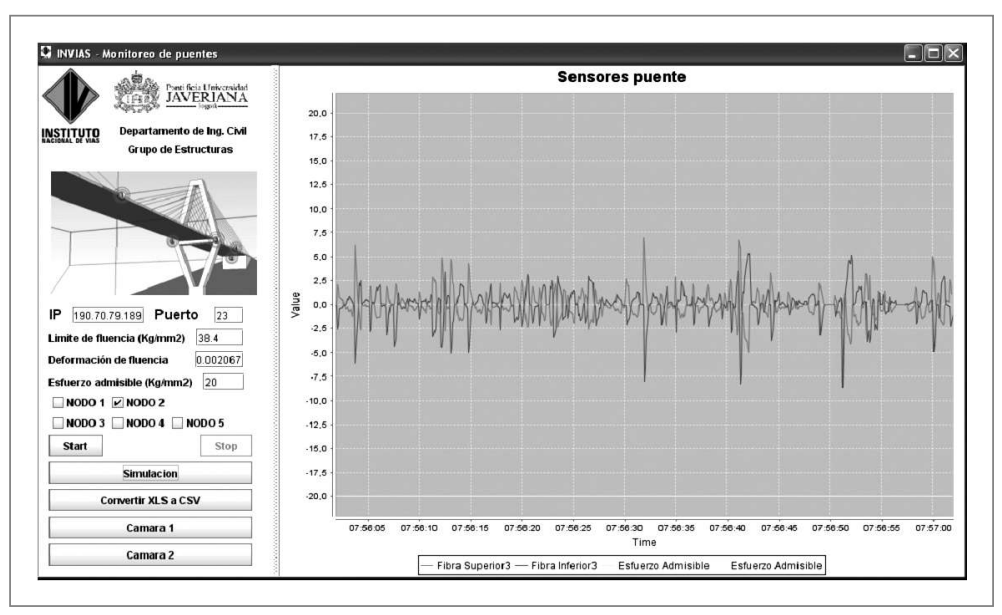

Figura 22. Programa para visualizar datos de esfuerzos de cualquier nodo Figure 22 . Software enabling the view of stress strength from any node

2.5 Verification of tension strengths of bridge's wire strainers

Wire strainers are major components in these kinds of bridges. Such components must bear different levels of tension strengths during their construction periods, fulfilling the international recommendations and requirements valid by at that time. According to references by Marin, J.M . (1999), specifications established by PTI ("PO ST TEN SIO N IN G IN STITUTE"), were employed for the design and construction of wire strainers of this bridge. The most important are listed below:

- Maximum tension strength of wire strainers shall not exceed $56 \%$ latest guaranteed tensile strength, Fpu.

- Strength difference of wire strainers, in one side of the tower, shall not exceed $15 \%$ wire strengths in the other side, at any moment during tensioning operation.

- Final tension strengths shall be adjusted to work at $40 \%$ Fpu under dead load service and at 45\% Fpu under normal overload service, as consigned by Group I, AASHTO.

- Wire strainers must have the strength capacity to structurally bear any load (dead or normal overload plus their impacts), supported by the bridge deck during its lifetime (service), and to properly transmit it towards pylons, which in turn must do the same towards foundations. Besides, wire strainers must not have any failure or structural instability due to fatigue effects. 
Based on such specifications, an assessment on tension strength levels was made on every single 72 wire strainers, during construction process. For that reason, the job site log-book was compiled, which explains each stage and some unforeseen situations. Such information was also found in input data belonging to structural analysis program AD APT-ABI plane, used by Inventory $M$ anagement for geometry control of this structure. In this way, such process was rebuilt as a structural model, using the "Staged Construction" module on SAP-2000 software, which allowed the review of stress records for each 72 wire strainers and for other elements of the bridge. At the same time, the effective strengths at the bridge's time of delivery (1997) were provided to us, which are shown in Figure 23.

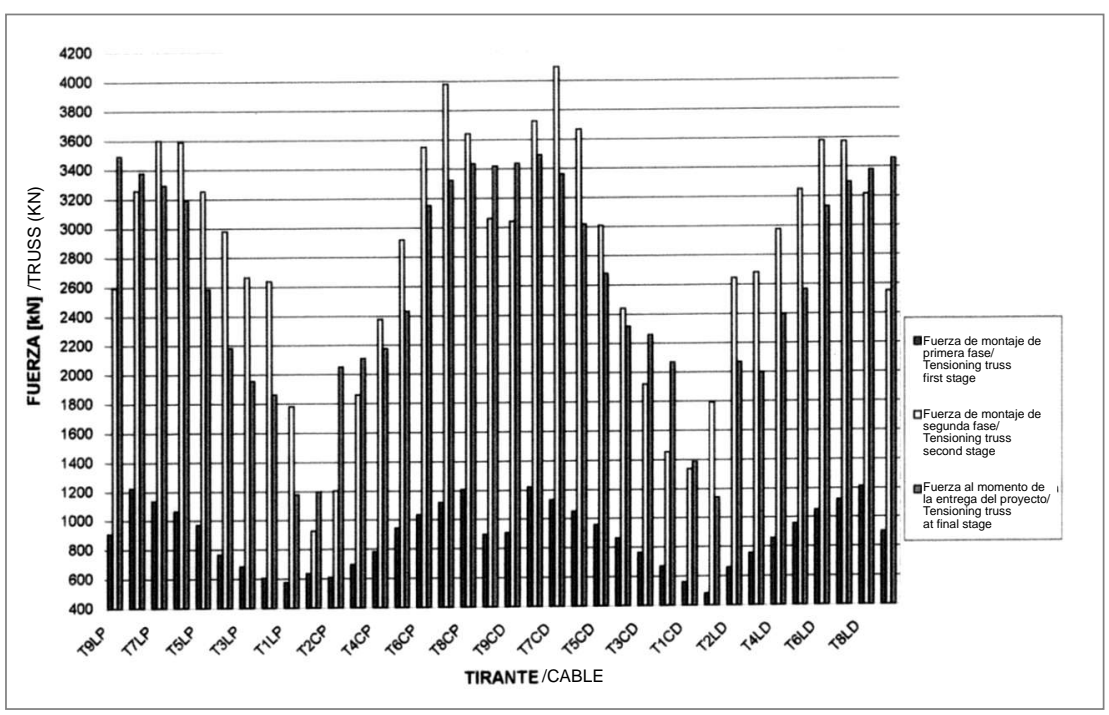

Figura 23. Fuerzas de montaje de primera fase, segunda fase y de entrega de proyecto - Fuente: Marín, J.M (1999) Figure 23. Assembly strengths for first phase, second phase and delivery of the project - Source Marín, J.M (1999)

Because of the relevance of this subject on the bridge diagnosis, a verification of tension strengths on three wire strainers was done, under non-traffic condition (See Figure 1), by uncovering their anchorages with the cooperation of VSL International Company. Above was achieved through IN VIAS and ICAGEL Company, which sub-contracted such service. 


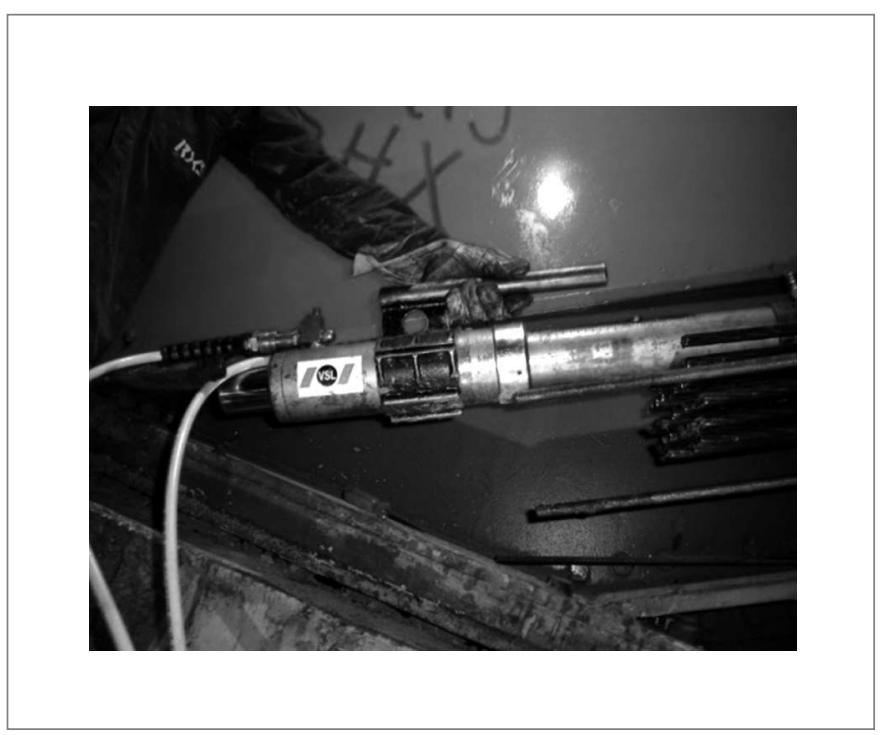

Figura 24. (a) Anclaje destapado para la medición de la tensión de tirante Figure 24. Uncovered anchorage for the tension measurement of wire strainer

So as to indirectly find tension values of some other wire strainers, without uncovering their anchorages, a mechanical-electrical system was developed, which was well capable of measuring natural frequencies of such wire strainers, thus allowing the estimation of their tension strengths. For such activity diverse analytical and empirical methods were employed, that were developed at an international level, which were found in (Wei-Xin, et al., 2005), (Byeong, et al., 2007), among others. It was achieved by the consultancy of the Electronic Engineering D epartment of the U niversidad Javieriana, and included the development of a software application in MATLAB, which takes the signal (accelerometer: time v/s accelerations), filters (avoids noises, etc.) and determines predominant frequencies (peaks) by using Fourier conversion method. This application was complemented by means of a degree research work of the Civil Engineering Career, which improved its reliability and application. The results obtained for T9LD cable, are shown below, which were also mechanically verified as previously mentioned. Figure 25 shows the signal obtained filtered and converted by Fourier method and the predominant frequency. 

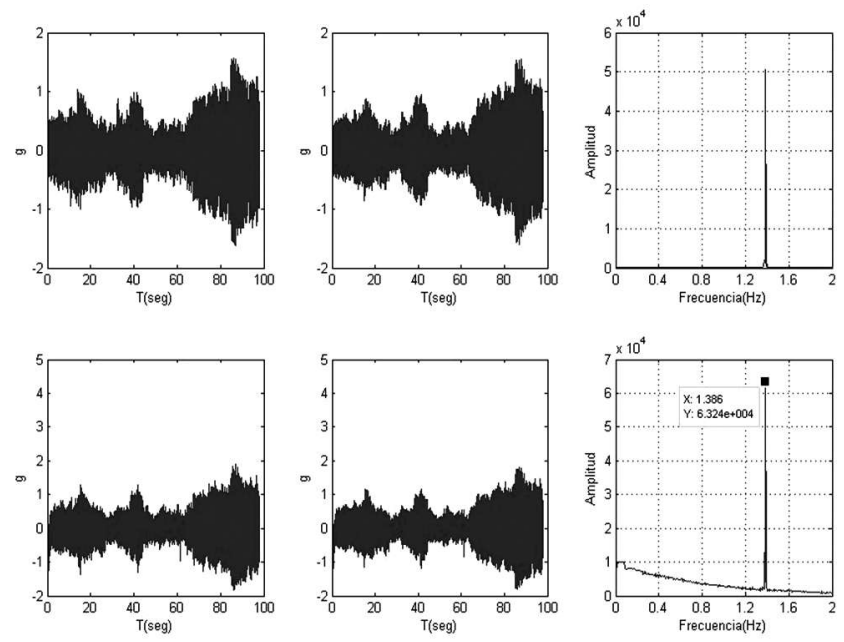

Figura 25. Resultados de frecuencia de los dos(2) acelerómetros en cable T9LD centro de la luz. (Acelerograma sin filtrar, acelerograma filtrado y transformada de Fourier)

Figure 25. Results of two accelerometer frequency of T9LD cable (non-filtered Accelerogram, filtered Accelerogram and Fourier conversion method)

For such wire strainer the following tension strengths were obtained by using five (5) international methods, obtaining a $0.49 \%$ error in method 5 , which offers an excellent reliability (See Figure 26). With this methodology diverse viaduct wire strainers were reviewed, without the need of uncovering their anchorages, and tension strength values were found, as well as their standard conditions on both sides of the road.

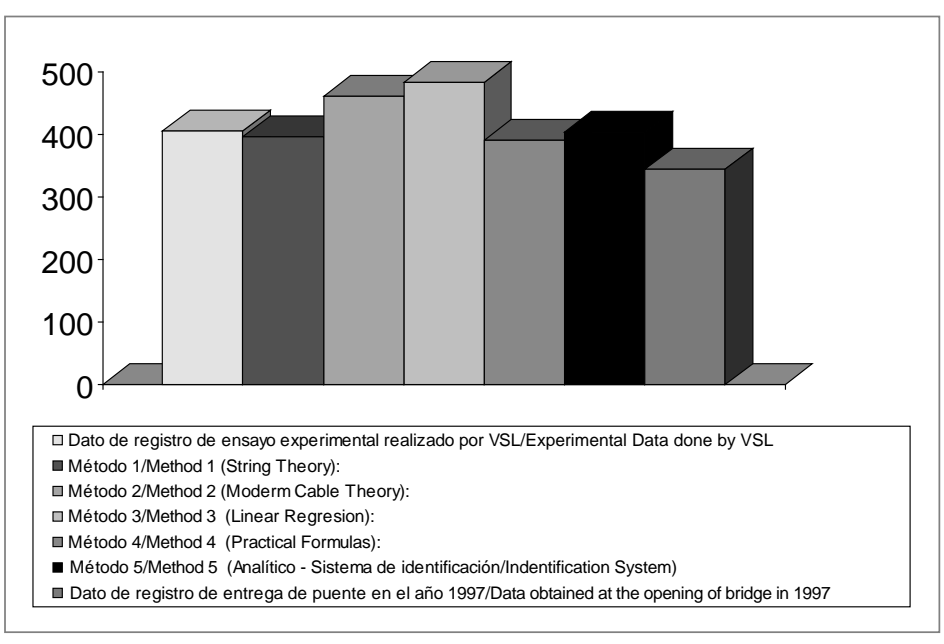

Figura 26. Tensiones estimadas para el tirante T9LD. Fuente : (Bohorquez, et al., 2009) Figure 26. Estimate tension strengths on wire strainer T9LD. Source: (Bohorquez, et al., 2009) 
Tension strengths were determined on two wire strainers by uncovering their anchorages, and values greater than $0.45 \mathrm{Fpu}$ were found (between 0.49 and $0.51 \mathrm{Fpu}$ ) recommended by the international regulation. Figure 27 and Figure 28 indicate the relation between tension strengths on wire strainers divided at admissible tension and the levels of tension in regards to Fpu.

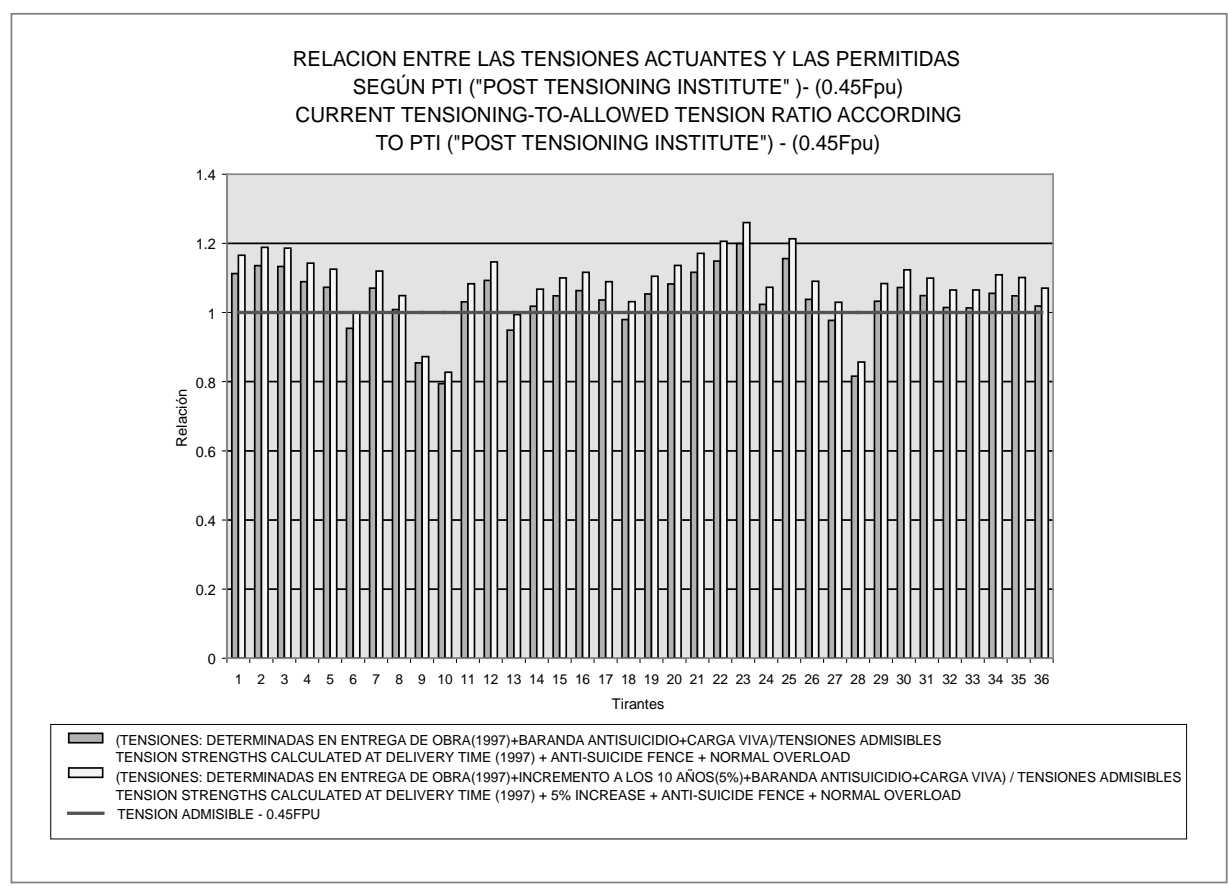

Figura 27. Relación entre fuerza de tensión actuante con la resistente $(0.45 \mathrm{fpu})$ Figure 27. Relation between tension strength interacting with the resistant $(0.45 \mathrm{Fpu})$

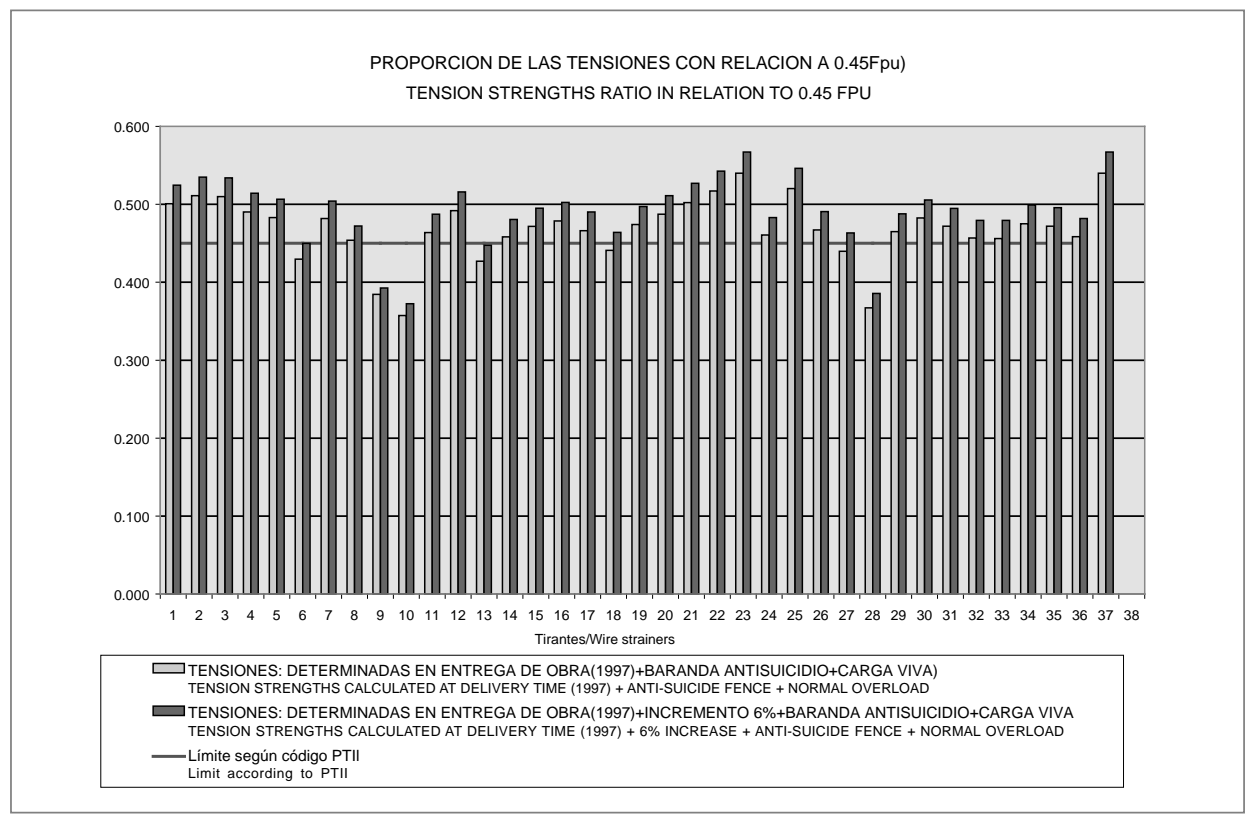

Figura 28. Niveles de tensiones con respecto a Fpu Figure 28. Tension strength levels in relation to Fpu 
Above figures are based on the following considerations:

o Records of tension strengths on each wire strainer taken by the time the bridge was delivered,1997 (See Figure 23)

o Tension strengths produced by normal overload, determined by the calibrated structural model (Model 1).

o Tension strengths produced by additional dead load (safety fences - anti suicide), determined by the calibrated structural model (Model 1).

o Consideration that tension strengths have increased app. $6 \%$ due to relaxation, temperature and other effects. It was also proven by estimating tension strengths through natural frequency.

\section{Results analysis}

\subsection{Structural Reliability}

This structure was evaluated by employing structural reliability techniques, which are the bases on which codes have been calibrated and implemented worldwide. For that reason, nominal values of safety factors and other coefficients indicated by such codes are mostly calculated by means of this theory, which purpose is to keep the structure at an operation level far away from failures, or at least with a failure probability close to zero. Since failure probabilities $(P f)$ are quite small (around $10^{-5}$ ), codes use a reliability index $(\beta)$ in order to facilitate the analysis on obtained values. The index is defined as follows:

$\beta=\Phi^{-1}\left(P_{f}\right)$

Inverse proportionality existing between $\beta$ and Pf shown in above equation, where minor failure probability in relation to reliability index, indicate good structure safety. For that purpose reliability techniques will be employed, which consists of verifying the closeness between (R) strength curves and tensile stress (S). When $G$ function is negative the structure is under failure condition, when $G$ is greater than zero the structure safety is acceptable, and when it is equal to zero the structure is under critical condition. For the case of random distributed variables $\mathrm{R}$ and $\mathrm{S}$, distribution probability functions are assumed, as well as non-correlation between them. Safety margin can be expressed as: 


$$
G=R-S=0
$$

Distribution of limit function $(G)$ is determined by this failure zone where the media of function $(G)\left(m_{G}\right)$ is proportional to standard deviation $\left(S_{G}\right)$. The proportion of these two parameters is reliability index $(\beta)$, hence, it assumes a normal distribution that can be evaluated as:

$$
\begin{gathered}
m_{G}=\beta \cdot s_{G} \quad(4) \\
\beta=\frac{m_{G}}{s_{G}}=\frac{m_{R}-m_{S}}{\sqrt{s_{R}^{2}+s_{S}^{2}}}
\end{gathered}
$$

Where:

$m_{R}$ : media of distribution strength $\mathrm{m}_{\mathrm{S}}$ : media of tensile stress strength

$S_{R}$ : standard deviation of distribution strength $\mathrm{S}_{\mathrm{S}}$ : Standard deviation of tensile stress strength

For the analysis of structural reliability on this bridge, worldwide recommendations were employed, which are related to failure probability ranges permitted for structures. These are fundamental parameters, on which every country has calibrated the corresponding codes. Accordingly, risk conditions for this structure will be reviewed, taking into account the following references:

- European code has been calibrated for a maximum failure probability, between $\mathrm{Pf}=10^{-4}$ and $\mathrm{Pf}=10^{-6}$ (Sobrino J. et al., 1993). Reference document nr. 1, Vol. 3 "Traffic loads on bridges" by EU RO CODE. In terms of reliability indexes these failure probability ranges correspond to $3.5 \leq \beta \leq 4.5$.

- American and Canadian codes (AASTHO y O NTARIO) accept a 0.001 failure probability, which corresponds to $\beta=3.09$ reliability index.

On the other side, for the analysis on structural reliability probability density curves were selected (standard, logistic, Log-standard, extreme value, etc.), which fit into strength and tensile stress strength functions, by using the goodness of fit technique for the adjustment of accumulated probability density curve by Kolgomorov-Smirnov. By means of Equation 5, the reliability index $(\beta)$ was determined, which is used even for distribution probability functions different the standard, with satisfactory results. Such statement is based on recommendations by some international authors(Mays, L, et al., 1992 and Ang. A.H-S, 1973), 
who consider this procedure as approximated, with minimum error, and acceptable. Consequently, this consideration was proven in the present paper, by using numerical integration and the determination of $G$ resulting curve. Failure probability was calculated, which corresponds to the area below $G$ curve, that is located between $-\alpha$ and zero point (0), i.e. when the tensile stress curve exceeds the strength (R). Besides, media and standard deviation were determined for $G$ resulting function and it was standardized. Afterwards, reliability index was determined (ß), which is the inverse variation coefficient of safety margin.

\subsubsection{For vertical loads}

The real time information related to instrumented bridge's elements yielded the following reliability indexes:

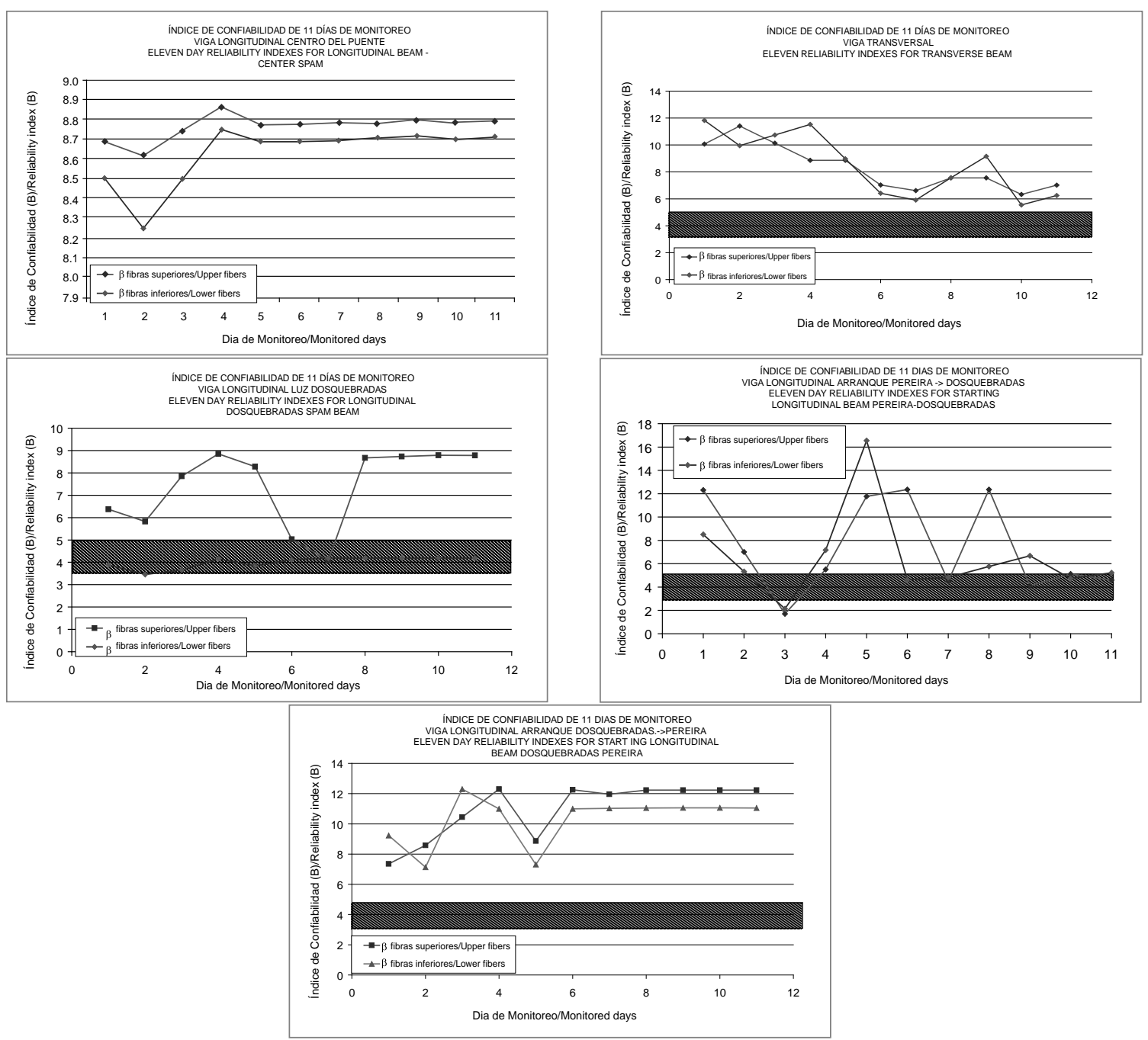

Figura 29. Índices de confiabilidad de: (a) viga longitudinal centro (b) Luz Dos Q uebradas (c) viga transversal. (d) viga longitudinal arranque Pereira - Dosquebradas.(e) viga longitudinal arranque Dosquebradas - Pereira Figure 29. Reliability indexes for: (a) central longitudinal beam (b) Span Dosquebradas (c) transverse beam. (d) longitudinal beam, springing Pereira - D osquebradas (e) longitudinal beam, springing D osquebradas - Pereira 


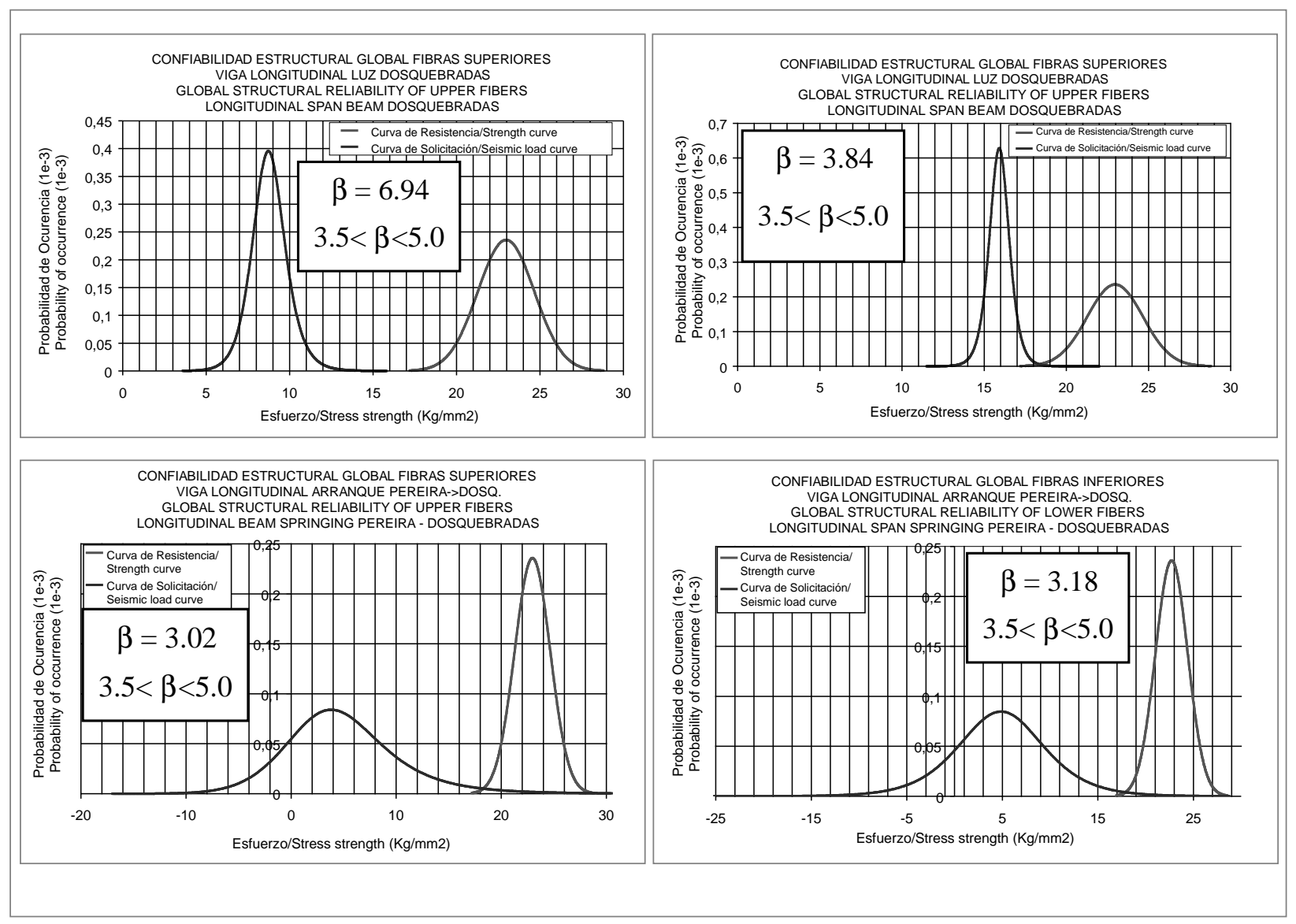

Figura 30. Cruce de curvas Resistencia Vs. Solicitación para los elementos con menores índices de confiabilidad Figure 30. Crossover of Strength v/s tensile stress curves for elements having minor reliability indexes

\subsubsection{For seismic loads}

In order to conduct the reliability analysis on the bridge elements from a dynamic point of view, it was necessary to estimate the response variation factor for such structure, thus evaluating its inelastic behavior as close as possible. For that purpose the recommendations by the reference regulation [ATC-19] were used, which state that for estimating such factor for any structure, it is necessary to evaluate the reserved strength of the structure, its ductility and redundancy. Above is explained in detail in the references provided by [Ruíz D. et al., 2002] and [Valencia C. G. et al., 2008]), where R value can be expressed based on the strength, ductility and redundancy. In order to evaluate strength factors and the structure ductility it was necessary to conduct a "Pushover" lineal static analysis, using the recommendations provided by ATC-40 regulation. This curve was based on an increasing strength up to the structure failure, corresponding to $100 \%$ in transverse direction and $30 \%$ in longitudinal direction. 
Ductility factor is associated to the maximum additional displacement, which defines the elastic limit for a system at a degree of freedom, that generally describes its stiffness function by means of an elastic-plastic curve (See [Ruíz, D. et al., 2002]). In accordance with ATC-19 the ductility to the $U$ displacement is calculated as the basal shear for a net elastic response divided by the maximum basal shear of the "Pushover" lineal elastic analysis. In this bridge a damping coefficient regarding critic condition was considered at $5 \%$, therefore its redundancy factor is 1.0. Based on obtained results for three individual factors, energy dissipation coefficient ( $R$ ) of this structure is greater than 5.0 (based on a retum period spectrum of 475 years). Determined reliability indexes curves are shown below:

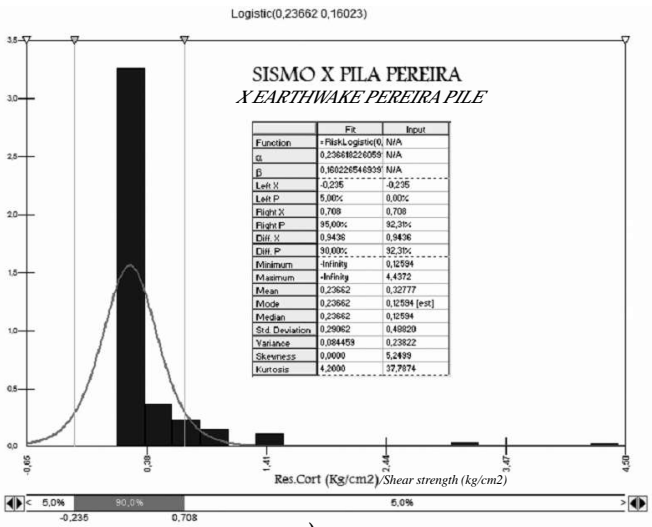

a)

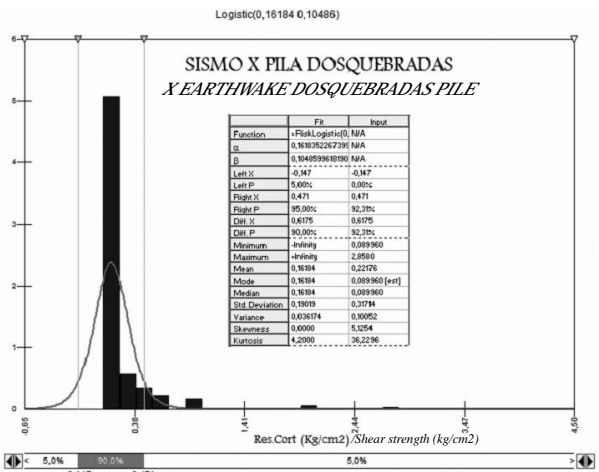

c)

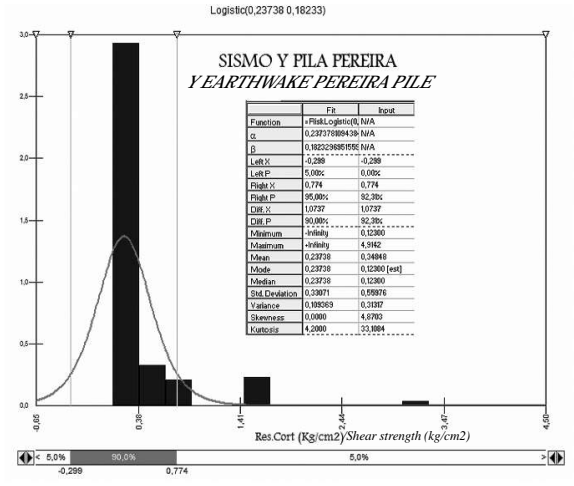

b)

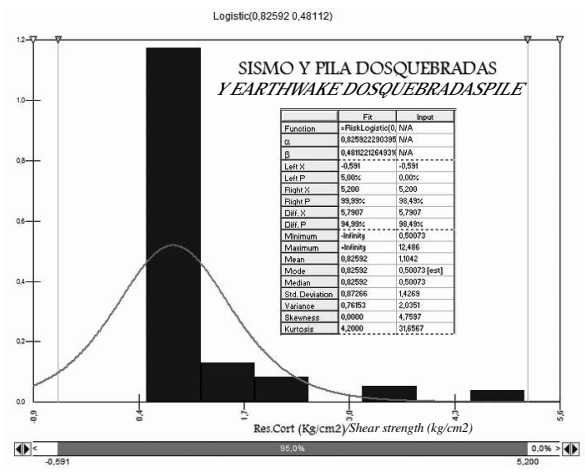

d)

Figura 31. Curvas de probabilidad del sismo en: (a) Dirección transversal del pilón de Pereira. $B=14.99$.

(b) dirección longitudinal del pilón de Pereira. $B=14.53$. (c) dirección transversal del pilón D osquebradas. $B=16.15$.

(d) dirección longitudinal del pilón de Dosquebradas. $\mathrm{B}=8.48$

Figure 31. Seismic probability curves: (a) Transverse direction of Pereira pylon. $B=14.99$.

(b) Longitudinal direction of Pereira pylon. $B=14.53$. (c) Transverse direction of D osquebradas pylon. $B=16.15$.

(d) Longitudinal direction of D osquebradas pylon. $B=8.48$ 


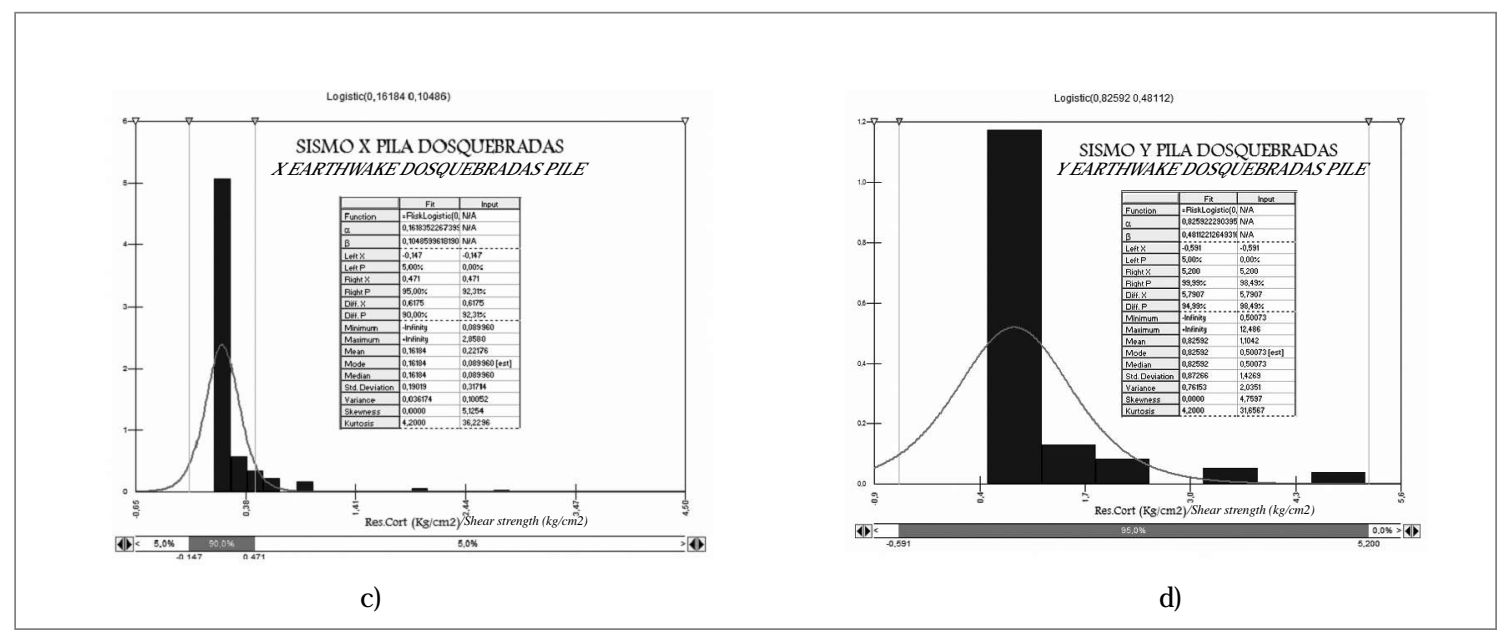

Figura 32. Curva de probabilidad por sismo (a) Dirección transversal del pilón de Pereira. $B=14.99$.

(b) dirección longitudinal del pilón de Pereira. $B=14.53$.(c) dirección transversal del pilón Dosquebradas. B=16.15.

(d) Dirección longitudinal del pilón de Dosquebradas. $B=8.48$

Figure 32. Seismic probability Curves: (a) Transverse direction of Pereira pylon. B=14.99.

(b) Longitudinal direction of Pereira pylon. $B=14.53$. (c) Transverse direction of D osquebradas pylon. $B=16.15$.

(d) Longitudinal direction of D osquebradas pylon. $B=8.48$

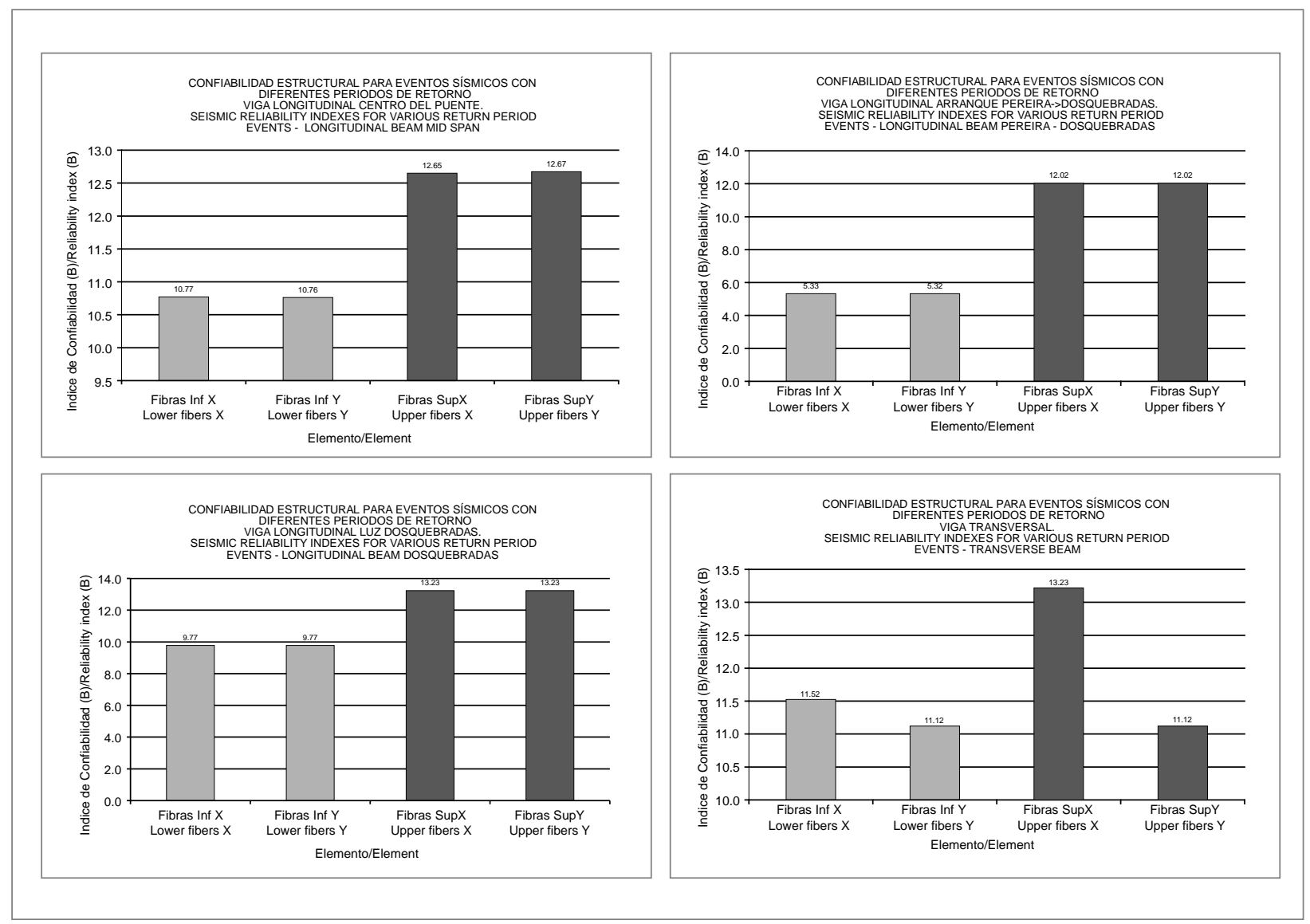

Figura 33. Índice de confiabilidad de: (a) elemento longitudinal centro del puente.(b) de la viga de la luz Dosquebradas. (c) viga del arranque Pereira - Dosquebradas. (d) viga transversal

Figure 33. Reliability indexes: (a) longitudinal element, bridges' center section (b) Dosquebradas span beam.

(c) Beam springing Pereira- Dosquebradas (d) Transverse beam 


\section{Conclusions and recommendations}

Conclusions from the assessment study on seismic vulnerability and loading capacity, by means of structural reliability, supported by monitoring and instrumentation of this bridge, are the following:

- It was found that one out of five monitored elements, has higher failure probability than the specified by European ( $\mathrm{Pf}=0.0001$ ) and American regulations $(\mathrm{Pf}=0.001)$. This is the longitudinal beam of Dosquebradas springing pylon, which had significant stress records during the bridge constructive process, and additionally, in some cases it has stress strengths higher than the ones load C40-95 would generate, thus, it must bear representative levels of negative bending moments produced by traffic load. Therefore, such element does not meet basic safety standards and its risk is moderate, which has been taken into account by INVIAS for rehabilitation work.

- Based on the study of local effects in the zone the bridge is founded, nine (9) spectrums were determined, at different return periods. By employing a concrete strength probability curve on pylons, it was found that such elements have failure probabilities lower than the ones permitted by the European code $(\mathrm{Pf}=0.0001)$ and American code $(\mathrm{Pf}=0.001)$. Therefore, it is concluded that pylons of this bridge have a satisfactorily structural capacity faced to a seismic event, since they were constructed under ductility, resistance and stiffness standards in accordance with seismic loads expected for this zone. This analysis was also made on instrumented elements, finding that they are in accordance with safety standards at minimum risk.

- It was also found that at least $40 \%$ wire strainers in this bridge have tension strengths higher than permitted by the design specifications and actual recommendations in the code by "POST TEN SIONING IN STITUTE" -PTI, thus concluding that they do not meet minimum safety standards in relation to strength and fatigue conditions. Tension fracture strengths vary from 0.35 to 0.55 (Fpu), in some cases being higher than admissible tension strength $(0.45 \mathrm{fpu})$.

These results were delivered to the Instituto Nacional de Vias and to ICAGEL Company, which were used as input for diagnosis, maintenance, updating and rehabilitation activities of such viaduct. 


\section{Acknowledgements}

The authors express their acknowledgements to the Instituto Nacional de Vias, for the logistic and economical support during the project development. Special thanks to engineers Virginia Ramos and Libardo Santacruz. Also to all engineering companies that provided information and know-how during the bridge construction, and especially to engineers Juan M auricio Marin, Jorge Molina and Ricardo Valderrama. Finally, their appreciation to engineer $D$ aniel Ruiz, for the references he provided for the seismic analysis on this bridge.

\section{Referencias / References}

Ambraseys N. N., Simpson K. A. y Bommer J. J. (1996), Prediction of horizontal response spectra in Europe. Earthquake engineering and Structural Dynamics, Vol. 25, 371-446.

ADAPT ${ }^{\circledR}$ (1997), ADAPT - Structural Concrete Software. 1733 Woodside Road, Suite 220 Redwood City, California 94061 USA. Ang A.H.-S. (1973), Structural Risk Analysis and Reliability-Based Design. Journal of Structural Engineering Division, 99, 1973, Pag 2035

Applied Technology Council - ATC 19 (1995), Structural response modification factors. Applied Technology Council. 555 Twin Dolphin Drive, Suite 550. Redwood City, California 94065.

Applied Technology Council - ATC 40 (1996), Seismic evaluation and Retrofit of Concrete Buildings. Applied Technology Council. 555 Twin Dolphin Drive, Suite 550. Redwood City, California 94065

Asociación Colombiana de Ingeniería Sísmica - AIS (1996), Estudio general de amenaza sísmica de Colombia. Asociación Colombina de Ingeniería Sísmica (1995), Código Colombiano de Diseño Sísmico de puentes. Instituto Nacional de Vías, Bogotá, Colombia.

Byeong. H, Taehyo P. (2007), Estimation of cable tension force using the frequency-based system identification method. Journal of Sound and Vibration 304 (2007) 660-676

Binaria Ltda (2006), "Estudio de vibraciones ambientales del puente de la Avenida calle 170 por autopista Norte", Trabajo de consultoría desarrollado para el Instituto de Desarrollo U rbano (IDU-Bogotá).

CSA S6.1-00. (2000), Canadian Highway Bridge Design Code. Canadian Standards Association.

European Committee for Standardization. Eurocode. (1993). Basic of Design an Action on Structures, Vol 3. Loads of Bridge. 10th draft Gallego Mauricio (2007), "Evaluación dinámica de dos(2) puentes peatonales de Bogotá", Trabajo para el Instituto de Desarrollo U rbano(IDU - Bogotá), Binaria Ltda.

Gómez Araujo, Iván Diario (2010), “Caracterización dinámica experimental de puentes de hormigón simplemente apoyados a partir de mediciones de vibración ambiental”, Tesis para lograr el título de Maestría en Ingeniería Civil, Directora: Dra. Esperanza Maldonado Rondon, U niversidad Industrial de Santander, Bucaramanga, Colombia

Johnson R. A. (1973), An earthquake spectrum prediction technique. Bulletin of the Seismological Society of America, Vol 63, 12551274.

Marin J.M. (1999), Control de geometría de la construcción incremental del viaducto Pereira - Dos Quebradas. Tesis de Grado, Especialización de Estructuras, U niversidad N acional de Colombia (Sede Medellín).

Mays. L, Tung Y. (1992), Hydrosystems Engineering and Management. McGraw Hill Series in Water Resources and Environmental Engineering. New York: Mc Graw Hill

Mc Guire R. K. (1977), Seismic design spectra and mapping procedures using hazard analysis based directly on oscillator response. Earthquake engineering and structural dynamics, Vol. 5, 211-234.

Muñoz E.E., Daza R.D. y O bregón N. (2002), “M etodología de evaluación estructural de puentes metálicos por técnicas de fiabilidad estructural". Revista Ingeniería de Construcción, Pontificia U niversidad Católica de Chile ,Chile.

Muñoz E.E., Valbuena E.A. (2005), “Evaluación de un puente en acero mediante criterios de confiabilidad parcial”, Revista Rutas, España. 
Muñoz E.E., Nuñez F., O tálora C. (2006), “Evaluación por confiabilidad estructural de puentes en acero apoyados en monitoreo e instrumentación", Revista Ingeniería de Construcción, Pontificia Universidad Católica de Chile, Chile.

M uñoz, E.E, Rodríguez, Jorge A.A, Nuñez, F. O tálora, C. Ramos, A (2008), “Vulnerabilidad sísmica y capacidad de carga de un puente en acero basado en confiabilidad estructural", Revista Ingeniería de Construcción, Pontificia Universidad Católica de Chile, Chile.

Newmark N. M. y Hall W. J. (1982). Earthquake spectra and design. EERI monograph, Berkeley, California.

O rdaz. M. (2002), DEG TRA 2000. U niversidad Nacional Autónoma de México - UNAM.

PLAXIS $®(2008)$, Version 8.0 Professional. 2600 AN DELFT The Netherlands.

Pontificia U niversidad Javeriana (2008), Informe Final Viaducto Pereira-D osquebradas. Proyecto "Aunar esfuerzos técnicos y financieros para incrementar la seguridad y estabilidad del viaducto Cesar Gaviria Trujillo de la carretera solución vial - Pereira - Dos quebradas (Ruta 29 RSA) y del puente Cajamarca en la carretera La Línea - Ibagué. Convenio con IN VIAS.

Ruiz. D, Sarria. M. (2002), Efecto de las diferentes componentes sísmicas de movimiento sobre las naves industriales de grandes luces. Revista de Ingeniería. Bogotá. No. 15 (Abr., 2002). - p. 46-55. U niversidad de los Andes

Sarrazin Mauricio, Moroni M. O., Q uintana Romo y Soto P. (2000), "RESPUESTA SíSMICA DE PUENTES CHILEN OS CON APOYOS AISLANTES", Departamento de Ingeniería Civil de la Facultad de Ciencias Físicas y Matemáticas de la U niversidad de Chile, REVISTA INTERNACIONAL DE DESASTRES NATURALES, ACCIDENTES E INFRAESTRUCTURA CIVIL, U niversidad de Puerto Rico.

Randall J. Allemang (2003), "The modal Assurance Criterion - Twenty Years of U se and Abuse", Journals Sound And Vibration, Estados Unidos.

Sobrino Juan A. y Casas R. (1993), M etodología de Evaluación Estructural de Puentes Existentes: Aplicación a un caso Real. En: Hormigón y Acero. Barcelona. UPC. IV Trimestre. P. 107-124.

Tanner Peter y Sobrino Almunia Juan Antonio (1998), ¿Cuánta Seguridad Necesitan las Estructuras? Calibración de Códigos. En: Curso de Estudios Mayores de la Construcción. (1998: Barcelona). Fiabilidad Estructural. Tratamiento de las Acciones Especiales. 19 p.

Thomson P., Galindez N., M arulanda J., O rozco A., Caicedo J., S. Dyke ( 2003), "Implementation of a modal identification methodology on the Pereira -Dosquebradas Viaduc, Asce - Engineering Mechanics Conference, Estados U nidos.

Wei-Xin R., Gang C. y Wei-Hua H. (2005), Empirical formulas to estimate cable tension by cable fundamental frequency. Structural Engineering and Mechanics, Vol. 20, No. 3 (2005) 363-380.

Valencia G. C., Valencia D. R. (2008), "Evaluación del coeficiente de disipación de energía, R, para algunos tipos de estructuras de acero" Ingeniería e Investigación, Universidad Nacional de Colombia, ISSN 0129-5608, No. 1, 2008. Pags. 41-49. 